\title{
Enabling ecosystem services at the neighborhood scale while allowing for urban regrowth: the case of Halle, Germany
}

\author{
Dagmar Haase $^{1,2}$ and Manuel Wolff ${ }^{1,3}$
}

\begin{abstract}
Cities that begin to regrow after a long period of decline and land abandonment are under pressure to provide comfortable housing conditions in preferred neighborhoods for their residents. On the other hand, these cities should preserve interim green spaces that result from decline because these spaces are a real treasure for densifying cities. Using the case of the city of Halle in post-socialist Eastern Germany, we explore four land use alternatives for neighborhood development close to what might happen: (1) urban densification, (2) spacious housing, (3) the green city, and (4) the edible city. We seek to discover opportunities for regrowth and sustainable land use development by applying the ecosystem services and green points frameworks to a set of land use transition rules. Land use change has been defined for strategic development areas according to the Master Plan and complementary visions of land change. The results of the study provide highly interesting insights into how both regrowth and greening can be enabled in densifying neighborhoods and what types of green are most effective in providing carbon storage and summer heat regulation. Moreover, gardens, as central elements of the edible city concept, were found to be flexible in implementation in very differently dynamic neighborhoods by providing multi-functional spaces for ecosystem services such as climate regulation, local food production, daily recreation, and nature experience. Results demonstrate that ecosystem services benefit flows increase only in districts where real estate pressure is low. In districts with growing population numbers, green spaces are reduced. This may result in increased injustice in green space availability seeing as we have modeled a recreational space per capita of $<9 \mathrm{~m}^{2}$ in the Southern Suburb, whereas an increase to almost $70 \mathrm{~m}^{2}$ was simulated in the shrinking, prefabricated Newtown. Most importantly, modeling the narratives of the Master Plan in a spatially explicit way demonstrates unused potential for greening in Halle. Thus, we conclude that urban planning should make regular use of such land use alternative to look for hidden combined visions of green and growth in a formerly shrinking city.
\end{abstract}

Key Words: ecosystem services; green infrastructure; Halle; land use alternatives; urban regrowth

\section{INTRODUCTION}

Growth in urbanization has been almost exponential over the last 150 years (McDonald et al. 2020). With an almost $80 \%$ urban population, Europe is one of the most urbanized regions of the world (UN 2019). Urban environments are enormously stressed by soil sealing, and the replacement of vegetation challenges the provision of ecosystem services (McPhearson et al. 2016). In addition, temperature increases and increasingly longer heat periods that can be linked to ongoing climate change (Andersson et al. 2019, Lin et al. 2021). The intense use of land for transportation and commerce is leading to high particle, black carbon, and nitrogen emissions and, as a kind of catalyst, a decrease in pollutant sinks in urban space itself because of the aforementioned replacement of vegetation (Larondelle et al. 2016, see the review by McDonald et al. 2020). This development is responsible for a decline in the natural buffer capacity of urban ecosystems for pollutants and carbon from the atmosphere (Ziter 2016).

Both the decrease in uptake capacity and the increase in sealed surfaces lead to severe consequences for urban nature and society, such as ecological fragility and human health problems (Kabisch and Kraemer 2020). The supply of ecosystem services (ES) is of increasing importance in cities at the beginning of the $21 \mathrm{st}$ century, and the development of more sustainable urban areas remains one key challenge. The Aalborg Charter (1994) and the Leipzig Charter entitled "Basis for Integrated Urban Development" from 2007, including its update in 2020, have already highlighted the pivotal role of communities, particularly that of (large) cities, in sustainable, green, and just development on the basis of resilient urban ecosystems. In this regard, the Leipzig Charter explicitly addresses the neighborhood level and the city as a whole and identifies urban policy for the common good as key for the success of such novel urban development agendas. In addition to strategic urban development plans, the Agenda 21 program has started to address climate change with local strategies (White 2002). In 2015, the topic of sustainable cities appeared to gain even more prominence on the global agenda with the formulation of the new Sustainable Development Goals (SDGs), again with a clear focus on urban regions and cities as being central to climate change mitigation, adaptation, and biodiversity conservation (Andersson et al. 2019, Elmqvist et al. 2019).

To date, however, the debate has almost completely neglected the fact that in some regions of the world, cities are not growing; they are or have been shrinking (Haase 2013, Haase et al. 2018). Whereas approximately $50 \%$ of European cities still grow, onethird of all large cities in Europe are losing population (Turok and Mykhnenko 2007, Wolff and Wiechmann 2018). Moreover, this number of shrinking cities has steadily increased in the last two decades, meaning that the number of potentially regrowing cities is currently increasing (Wolff and Wiechmann 2018). The main reasons for this shrinkage are systemic changes in society and the process of economic restructuring that started in 1990. Shrinkage is still, with decreasing dominance, determining population stocks and net migration (Pallagst et al. 2013, Wolff et al. 2017). Outmigration and demographic aging continuously cause housing oversupply, leading to residential vacancies, and temporarily falling rents in both old, built-up, and socialist

${ }^{1}$ Department of Geography, Humboldt-Universität zu Berlin, ${ }^{2}$ Department of Computational Landscape Ecology, Helmholtz Centre for Environmental Research (UFZ), ${ }^{3}$ Department of Urban and Environmental Sociology, Helmholtz Centre for Environmental Research (UFZ) 
prefabricated housing estates (Rink et al. 2012, Haase et al. 2016, Nelle et al. 2017). Recently, some shrinking cities in Central and Eastern Europe have started to regrow. Their number is still limited (Wolff and Wiechmann 2018), but their signaling effect for a comeback might be enormous. Both shrinking and regrowing cities have significant impacts on the built-up structure forming characteristic spatial patterns, in particular in terms of density changes (Wolff et al. 2017, 2018).

Therefore, legacies of shrinkage provide a specific framework for new land use development, with vacant land offering space for reuse, alternative and interim uses, and infill development (Schetke et al. 2010, 2012). In contrast, regrowth, conceptualized as population growth after a longer phase of shrinkage (Turok and Mykhnenko 2007, Wolff et al. 2018, Wolff and Wiechmann 2018), leads to heterogeneous and small-scale patterns of land use impacts with a predominant trend of strong redensification (Kabisch et al. 2010). It is also reported that, albeit with strong population regrowth, the corresponding cities still have limited strategic steering opportunities, mostly because of a lack of municipal budget (Wolff et al. 2017). Consequently, various alternative future land use states are imaginable. Therefore, for shrinking cities, reduced pressure on real estate and, thus, on urban land can be understood as an opportunity to increase green and blue infrastructure (GBI), which is the full range of flora and fauna ranging, from forests, parks, and gardens to single trees.

Consequently, the demographic regrowth of a city can challenge this potential. Shrinkage-related brownfields and open spaces created after demolition have become increasingly underrated as opportunities to increase both GBI and recreational space for the urban population, but they are increasingly targeted as areas for new construction (Haase et al. 2014a, Wolff and Haase 2019). Continuous growth following increasing population numbers and commercial activities has turned formerly shrinking cities back into concrete places where green space is missing, exhibiting bad and unfair environmental conditions for larger population groups (Anguelovski et al. 2020, Langemeyer and Conolly 2020). In contrast, many formerly shrinking cities have recognized late that the extension of existing GBI under conditions of vacancy and demolition has been a strategy not only for filling gaps but also for providing recreational spaces in their inner parts; thus, such extension could be a path for making cities more resilient. Therefore, GBI is understood as a response to mitigate urban densification and climate impacts that is beneficial to the individual health of residents, e.g., by air cooling, runoff water regulation, or $\mathrm{CO}_{2}$ mitigation (Pauleit et al. 2019 and the reviews by Haase et al. 2014b, Kabisch et al. 2015, van den Bosch and Ode Sang 2017). In addition to these regulating ecosystem services, GBI provides important cultural (e.g., recreation space) and provisioning (e.g., local food production) services. Referring to the enabling and hindering factors of GBI benefits, according to Andersson et al. (2021, in this Special Feature), formerly and recently shrinking cities seem to have great potential in the physical infrastructure sector, which clearly is a filter for enabling GBI-induced ecosystem service provision (Haase et al. 2014b).

In seeking sustainable and regrowth-balancing urban development, the challenges for a city with a shrinkage past, such as Halle, involve the prioritization and balancing of the ecosystem service potential with social requirements and economic demand
(Larondelle et al. 2016). One way of balancing densification and maintaining the provision of ecosystem services from GBI is the development of framings that guide growth in desired directions that acknowledge the aspects mentioned in the Leipzig Charter, such as green space as a common in a just city. Following such a framing idea, the urban master plan, the integrated development concept developed by the regrowing city of Halle, provides a vision up to 2025 (ISEK Master Plan of Halle 2016). The Halle Master Plan includes regrowth as one of the fundamental assumptions and future visions of and for the city. Halle is part of the former German Democratic Republic, and like other industrialized towns, the city experienced turbulent development after the German reunification in 1990, including a labor market crash (Pallagst et al. 2013) and the emergence of large industrial and transportation brownfields, followed by a population exodus and subsequent enormous housing vacancies (Haase et al. 2012, 2014a). This development can be expressed as urban shrinkage, and this shrinkage has determined the urban development of Halle for more than two decades since 1990 (Arnold et al. 2018). The study by Arnold et al. (2018) emphasizes that the central parts of Halle report limited capacities to provide ES because of compactness and land surfacing. Thus, the identification of potential for ES delivery improvement in these inner parts being of strategic interest to Halle's planners is key and in the best way complementary to what research reports so far for the city.

Currently, population development in Halle is trending toward diversity. Downtown areas are experiencing an immigration of young, educated people and small households (Bartholomae et al. 2017), vacancies are disappearing, and the existing GBI is under pressure to be removed. However, the areas of prefabricated housing estates such as Halle-Newtown and the former mixedindustry worker areas still suffer from a stagnating or declining population, a vacant housing stock, and many brown/greyfields (Haase et al. 2016).

Not exclusively in Halle but also in many other regrowing cities, this diversity of population trends creates pressure on urban land that is open, vacant but developed, or green (Wolff and Haase 2019). Even semi-public green spaces with high recreational value, such as allotment gardens, have been sacrificed for new housing estates for mostly high- and medium-income households (Spilková and Vágner 2016), not to mention successive green or wilderness areas, which have no real lobby to be maintained (Draus et al. 2021). However, many districts in formerly shrinking cities are still not built up. There is still a mix of vacant or dilapidated lots next to old or newly built housing estates (Wolff et al. 2017). In addition, following a kind of template strategy in cities worldwide (Haase 2013, Scott et al. 2016), new GBI has been created in vacant lots and in large brownfields, leftovers of the German Rail Company. Compared to rapidly regrowing cities such as neighboring Leipzig (Kabisch et al. 2019), in Halle, urban planners still face a large variety of options for either increasing density or greening their city because regrowth is occurring at a moderate pace.

By constraining the provision of ES from GBI for urban residents in various ways, the land use composition and configuration resulting from planning decisions can serve as systemic barriers to framing both the availability and accessibility of GBI (see Wolff et al. 2022, in this Special Feature). ES potential means flows from 
the ecosystem - in our case, urban GBI - toward human wellbeing to be experienced or realized (Haines-Young and Potschin 2010, Felipe-Lucia et al. 2015) —in our case, by the residents of Halle. Here, first and foremost, tangible/material benefits such as provisioning services (e.g., food) and intangible/immaterial benefits such as cultural services (e.g., recreation or relaxation) or regulating services (e.g., air cooling; Haase et al. 2014b, Baró et al. 2016) are excellent and widely used approaches to conceptualizing and quantifying GBI-induced benefits.

Set against this backdrop, the aim of this study is to explore a range of land use and neighborhood development alternatives. This study analyzes both regrowth and green development by applying the ES approach following an international classification (Common International Classification of Ecosystem Services [CICES], https://cices.eu/) to a set of land use change alternatives. In addition to the quantification of the total ES provided, special attention was paid to the differences, synergies, and trade-offs in ES provisioning at the local district scale. Based on the framing Master Plan of Halle, for four central and two more peripheral districts, we developed and analyzed four development alternatives, i.e., a green narrative, an edible city narrative, a spacious housing narrative, and a densification narrative, all translated into spatially explicit land use alternatives. Such information will be key for decisions about climate-sensitive and sustainable land development under regrowth in Halle and thus decisive for both municipal town planning but also neighborhood land developers.

The leading research questions of this study are as follows:

1. How does a set of land use alternatives based on the master plan alter land use composition in Halle's neighborhoods up to 2025 ?

2. How much can GBI improve local and citywide ES provisioning in the strategic development areas?

3. Which land use alternatives improve ES provisioning the most, and best favor the synergies between the different ES provided?

To address these questions, in the following, each land use alternative was developed in a spatially explicit way and mapped using a geographical information system (GIS) using the freely accessible Quantum GIS (QGIS). The GIS maps and other empirical data served as input layers for the quantification and assessment of ES potential.

\section{Study area}

The city of Halle is situated in the Central German lowlands on the Saale River. Halle is part of the federal state of SaxonyAnhalt. Currently, Halle has 237,000 inhabitants and has been undergoing population regrowth after a long period of shrinkage (Nelle et al. 2017). From its peak in 1988 Halle lost almost 99,000 inhabitants by 2011, but increased in population by 7400 up to 2020. The city is traversed by the Saale River and its remarkable floodplains, a composite of remnant broadleaf forests and diverse fluvial meadows. The floodplains constitute the largest and most precious feature of the GBI network in the city, consisting of several parks, nature protection areas, and leisure spaces (Fig. 1).
In 1920, Halle's population grew to over 200,000 inhabitants. During World War II, the city received moderate damage. As part of the German Democratic Republic, the expansion of industrial production around Halle-Merseburg-Bitterfeld in the 1960s followed from a centrally planned housing program for industrial workers (Rink et al. 2010). Prefabricated apartment blocks soon dominated the cityscape. Because historical buildings were seen as the remains of a capitalist past, construction and renovation activities occurred mostly in the new socialist suburbs of Halle.

One of these developments was Halle-Newtown, serving as home to over 90,000 urban residents. Halle's population peaked again in 1986 at 329,625 inhabitants (Rink et al. 2010). With German reunification in 1990, the city faced deindustrialization and the disappearance of thousands of jobs almost overnight, which led to high unemployment rates. Consequently, the city lost approximately 56,000 inhabitants, which was approximately $20 \%$ of its total population, based on job-driven outmigration (Rink et al. 2010). In addition, this time, mostly young families and the highly educated population left the region for better job opportunities (Haase et al. 2012, Nelle et al. 2017). Halle's real estate market was flooded with oversupply. In 2003, there were more than 310,000 vacant flats, amounting to one-fifth of the total housing stock (Rink et al. 2010). Unlike in the socialist era, after reunification, the prefabricated large-scale housing estates in Halle-Newtown and Silberhöhe lost their population. Both estates lost half of their former residents in the period from 2003 to 2012. Economic restructuring increased unemployment and promoted outmigration. Consequently, Halle, like many other Eastern German cities, faced severe population loss (Kroll et al. 2010).

In 2000, the largest urban renewal program Germany has ever implemented, Urban Restructuring (in German, Stadtumbau Ost), started after the federal government counted one million vacant flats within Eastern Germany (Nelle et al. 2017). The federal program aimed at the removal of permanent vacancies, the stabilization of urban centers, and the conservation of historic buildings. Before 2007, approximately 9000 flats were demolished in Halle. In the second stage, the International Building Exhibition (in German, Internationale Bauausstellung or IBA) was implemented as a "creative instrument" that provided incentives for new urban visions, including the use of green and blue elements when restructuring and rebuilding cities.

Following these incentives, Halle's planners developed a novel strategic urban development concept, the integrative Halle Master Plan (in German, Integriertes Stadtentwicklungskonzept or ISEK). The master plan is an urban development instrument that fosters the integrative co-development of land use (change) in the city and includes factors such as social justice and environmental qualities. One basic element of the Halle Master Plan is the envisioning of strategic changes in the city to build, as it is called in the plan, a "sustainable and balanced future." The master plan was issued in 2016 and is regularly updated. Detailed land development projects are defined at the local district level (in German, Stadtviertel), of which Halle has 26. The master plan vision for 2025 highlights six districts called "strategic development areas" in response to both of the dominant population trends mentioned above, i.e., shrinkage and regrowth: 
Fig. 1. The case study city of Halle: Green-blue infrastructure (GBI) and boundaries of the strategic development areas for which land use alternatives were developed (https://land.copernicus. eu/local/urban-atlas).

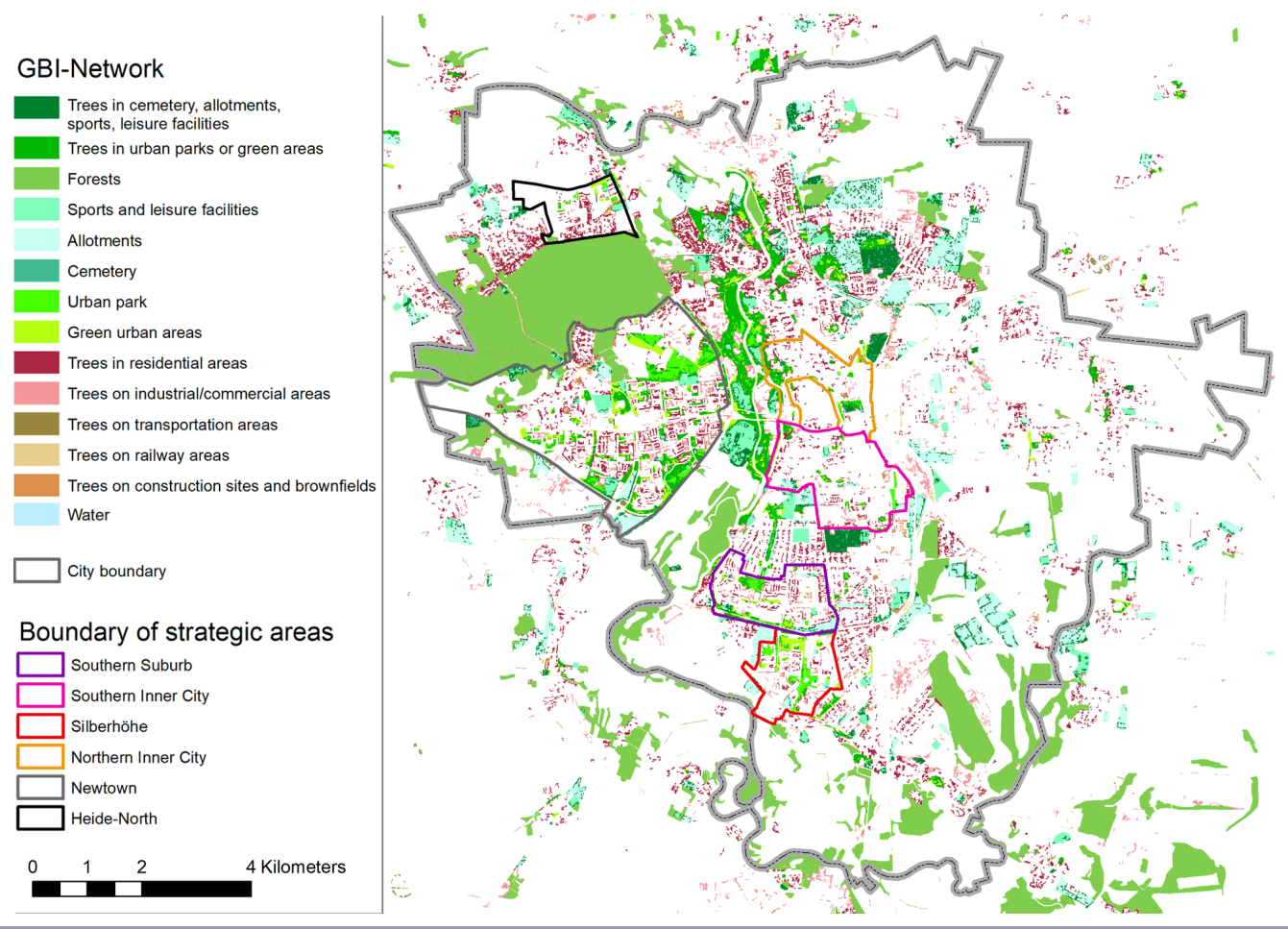

Center North, Center South, Heide-Nord, Silberhöhe, Southern Suburb, and Newtown (Fig. 2). These districts have been chosen be the local cases to be modeled in this study.

\section{MATERIAL AND METHODS}

\section{Land use data}

We used land use/cover data provided by the European Environment Agency (EEA) as part of the Urban Atlas project for the selection and definition of alternative land uses and for ES assessment (Copernicus, https://land.copernicus.eu/local/ urban-atlas). The Urban Atlas includes all European cities with more than 50,000 inhabitants. The database covers a wide range of land use classes, ranging from natural vegetation land cover to densely built structures (Table 1, Fig. 1). Because of its wide range of land use classes covered and its availability for many other European cities, the Urban Atlas database has been used to derive a set of land use change rules for the six strategic development areas of Halle introduced above (see the schematic sequence of working steps displayed in Fig. 3).

The Urban Atlas dataset has a 0.25-hectare geometric resolution, which is a good basis for neighborhood-scale ES assessment (as argued in Larondelle and Haase 2013 or Larondelle et al. 2016). In addition, the Urban Atlas data for each city are freely available and updated every three to five years (Copernicus); the last update was performed for the reference year 2018. Urban Atlas data were combined with another publicly available spatial dataset that is rich in information for urban areas, the OpenStreetMap (OSM). The OSM provides software for the crowd-like co-collection and
Table 1. Land use classes determining land use states in the scenarios according to Urban Atlas.

\begin{tabular}{|c|c|c|c|}
\hline $\begin{array}{l}\text { Residential land } \\
\text { cover }\end{array}$ & $\begin{array}{l}\text { Industry and } \\
\text { Commerce }\end{array}$ & $\begin{array}{l}\text { Urban green } \\
\text { and blue } \\
\text { infrastructure }\end{array}$ & Open land use \\
\hline $\begin{array}{l}\text { Continuous Urban } \\
\text { Fabric (sealing > } \\
80 \% \text { ) }\end{array}$ & $\begin{array}{l}\text { Fast transit roads } \\
\text { and associated } \\
\text { land }\end{array}$ & $\begin{array}{l}\text { Green urban } \\
\text { areas }\end{array}$ & $\begin{array}{l}\text { Agricultural } \\
\text { areas, } \\
\text { semi-natural } \\
\text { areas, and } \\
\text { wetlands }\end{array}$ \\
\hline $\begin{array}{l}\text { Discontinuous } \\
\text { Medium Density } \\
\text { Urban Fabric } \\
\text { (sealing } 30-50 \% \text { ) }\end{array}$ & $\begin{array}{l}\text { Other roads and } \\
\text { associated land }\end{array}$ & $\begin{array}{l}\text { Land without } \\
\text { current use } \\
\text { (brownfields) }\end{array}$ & Forests \\
\hline $\begin{array}{l}\text { Discontinuous Low } \\
\text { Density Urban } \\
\text { Fabric (sealing } 10- \\
30 \% \text { ) }\end{array}$ & $\begin{array}{l}\text { Railways and } \\
\text { associated land }\end{array}$ & $\begin{array}{l}\text { Sports and } \\
\text { leisure facilities }\end{array}$ & Water \\
\hline $\begin{array}{l}\text { Discontinuous Very } \\
\text { Low Density Urban } \\
\text { Fabric (sealing < } \\
10 \% \text { ) }\end{array}$ & $\begin{array}{l}\text { Port areas, } \\
\text { airports } \\
\text { Construction sites } \\
\text { Mineral } \\
\text { extraction, dump } \\
\text { sites }\end{array}$ & & \\
\hline
\end{tabular}

Source: Copernicus, https://land.copernicus.eu/local/urban-atlas 
Fig. 2. Profiles of the priority development neighborhoods of Halle for which land use alternatives were developed.

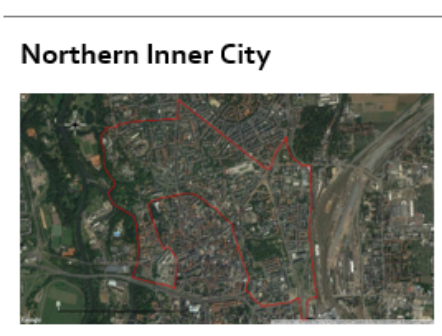

The district is part of the old town of Halle and the urban image was shaped in Wilhelminian times. The population in the Northern Inner City has been rapidly growing in recent years; 16,800 people live in the area. The population forecasts expect an ongoing demographic growth of about 18\% until 2030. Residential construction and redevelopment are the focus of the ISEK strategy. Undeveloped brownfields bear high development potential.

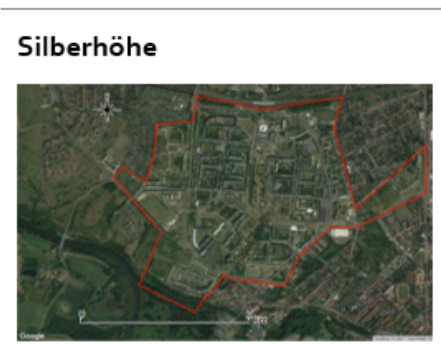

Silberhöhe is a prefabricated housing estate at the southern fringe of Halle. Built in the last years of the GDR, it was the second largest housing estate and was constructed for 40,000 workers. After reunification, Silberhöhe lost $40 \%$ of its population. Consequently, over 6000 flats were demolished. The new open spaces are used to realize the vision of a green and close-to-nature district called "forest-city by 2030 ", the population is predicted to decrease by $15 \%$.

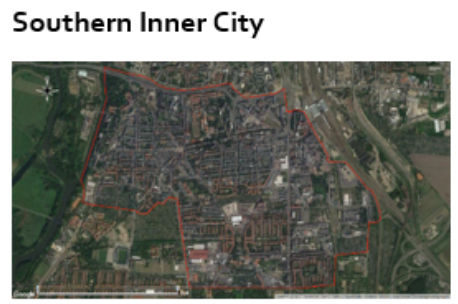

Similar to the Northern Inner City, the Southern Inner City was shaped in Wilhelminian times and has a lack of green spaces. Like the Northern Inner City, the Southern Inner City is undergoing a process of demographic growth. 29,700 people live in the district, but the forecasts expect that 34,300 people will live there by 2030 .

Development explicitly includes brownfields. The low green space availability is mentioned as a challenge.

\section{Southern suburb}

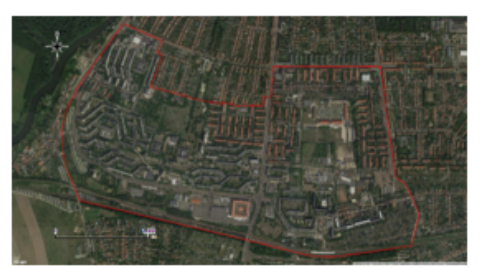

The Southern Suburb comprises a combination of apartment blocks and single-family houses.

Currently, 16,000 people live in the Southern Suburb but, because of demographic change, the population will shrink by about $21 \%$ in the coming years. After the phase of demolitions is complete, the challenge will be to carry out the conversion of the brownfield.

\section{Heide-North}

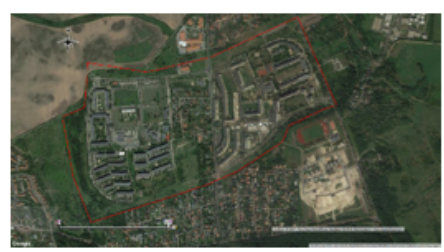

The development area, HeideNorth, is situated in the northwest of Halle. The development area for the ISEK 2025 includes the block district, Heide-North, and the singlefamily house district, Blumenau. Heide-North is the youngest block district in Halle, which was completed after reunification in 1991. The actual rate of vacancy is between $10-14 \%$. Because of demographic aging, the population is expected to shrink by about $16 \%$ in 2030. Blocks will be removed in favor of green.

\section{Halle-Newtown}

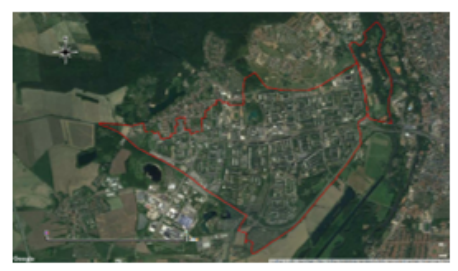

Halle-Newtown was the last city to be established in the GDR. Finished in 1967 , the city offered space for 94,000 workers from surrounding factories. Because of the structural change in the 1990s, Newtown lost over $50 \%$ of its population. Today, about 45, 000 people live in Newtown. The cityscape of Newtown is shaped by big blocks, but with integrated low-quality green areas. Within the coming years, the population is expected to shrink by about $11 \%$. The living quarters, $\mathrm{V}$ and $\mathrm{VI}$ will, therefore, be demolished. 
Fig. 3. Scheme showing the sequence of the single working steps of the integrated scenario building, scenario implementation, and green and blue infrastructure/ecosystem services (ES) flows analysis/assessment.

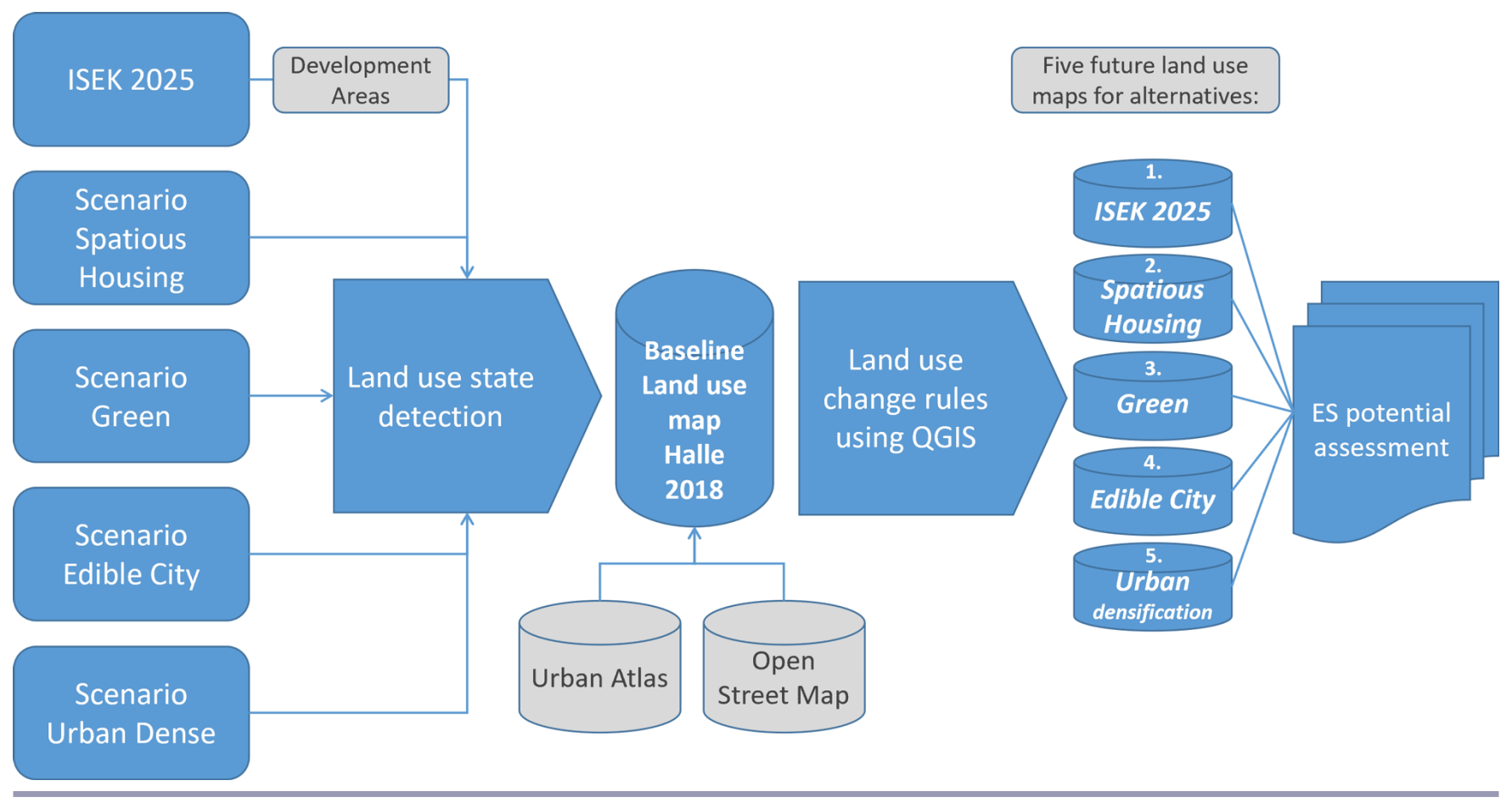

display of spatial data (https://www.openstreetmap.org/about). We used the OSM to identify the two land use classes that the Urban Atlas does not provide: urban gardens and (dense) urban areas.

\section{Building land use alternatives}

Land use alternatives are used to visualize and analyze the consequences of land development and land use change; thus, they help to shed light on the potential impacts on the state and functioning of the ecosystem during realization (Larondelle et al. 2016) and, thus, on the ES provided (Fig. 3). As Lauf et al. (2012a, b, 2014, 2016) demonstrated for Berlin, spatialized land use alternatives based on different narratives help to visualize where land cover and land use will alter, and which specific ecosystem impacts such alteration will have. As a result, estimations of the effects of land use change can be made and explored (Verburg et al. 2004). Stepwise rule-based land use change models (as shown later in Fig. 4) are frequently used and successfully applied in urban studies, as proven by many excellent studies (Ligtenberg et al. 2001, Barredo et al. 2003, Koomen et al. 2008, Larondelle et al. 2016, Lauf et al. 2012a, b, 2014, 2016).

All narratives for the six development areas in Halle are based on the "vision 2025" guidelines and goals outlined in the Halle Master Plan (ISEK Master Plan of Halle 2016). The strategic development areas and the respective narratives chosen in this paper (shown in Fig. 2 and Table 2) were developed in an iterative process, described in detail below.

We started with the hypothesis that the city of Halle will continue to grow after a long period of shrinkage. As stated above, shrinkage leads to a lower population density, residential vacancies, and the demolition of houses. Consequently, we have lower built densities and more open space in shrinking cities (Haase et al. 2014a). The Master Plan of Halle aims at sustainable regrowth, again allowing for a higher population and, thus, higher built densities in residential areas while maintaining environmental qualities that are under pressure when an area is being rebuilt.

Based on these goals and using studies about formerly shrinking and transforming cities (Larondelle et al. 2016, Wolff et al. 2017, 2018), we developed the four narratives of (1) urban densification, (2) spacious housing, (3) the green city, and (4) the edible city to translate both goals into land use alternatives. Urban densification and spacious housing allow for higher population densities and allow flats to be provided to new residents, whereas the green and edible city allow environmental qualities to be safeguarded (Table 2).

Based on Table 2, the narratives were translated into numbers and GIS rules to spatialize them (for the procedure, see Fig. 3, and for the change rules, see Table 3). By doing so, all elements listed in the narratives outlined in Figure 2, e.g., population growth, hot spots/cold spots for further land use change according to the announcements of the Master Plan, and expected rents based on current rent development in the Leipzig-Halle region (rent index in Halle, https://www.immowelt.de/immobilienpreise/halle-innenstadt/ mietspiegel), were increased or decreased relative to the current data/values. For example, when the Halle Master Plan foresees resettling/densifying a strategic development area, we built new houses $\left(\mathrm{t}_{1}\right)$ in this neighborhood on vacant ground $\left(\mathrm{t}_{0}\right)$ and filled it with households of the average household size of the city by 
Table 2. Narratives for the four alternative land use scenarios in agreement with the content of the Halle Master Plan (in German, ISEK): (1) urban densification, (2) spacious housing, (3) the green city, and (4) the edible city

\begin{tabular}{ll}
\hline \hline $\begin{array}{l}\text { Master plan ISEK } \\
\text { Vision for 2025 }\end{array}$ & $\begin{array}{l}\text { For the ISEK 2025 narrative, the announced projects within the urban development plan were assigned in } \\
\text { the QGIS and translated into new land uses. The result is a land use map from Halle in 2025 as the Master } \\
\text { Plan foresees. }\end{array}$
\end{tabular}

The green city This narrative is about the vision of urban greening. All the detected areas will be converted into public parks by 2025 . This development scenario goes together with the repeated intention shown by Halle to strengthen its image as the greenest city in Germany. An increase in green spaces would improve the wellbeing of the residents of Halle because of better environmental conditions and more recreational areas. Prefabricated districts as well as the old-town districts could profit from such development. For the green land use narrative, all areas assigned for transformation in the Master Plan are transformed into land use state "Green Urban Areas."

The edible city This narrative focuses on the enhancement of the provisioning ecosystem services. Therefore, the vacant areas are transformed into urban gardens and urban farms. The reintegration of food production in the city does not only increase the biodiversity and carbon sequestration, it can also contribute to a varied and healthy diet for urban residents and, therefore, improve the well-being of residents. Brownfields and vacant lots all over town could be used to grow food. The natural ability of plants to clean polluted soil would be an additional benefit for a formerly industrial town like Halle. Within this scenario, it is assumed that all the transformative areas are going to be converted into urban gardens and farms by 2025. In doing so, a new land use class was introduced: "urban gardens and farms."

Spacious housing The spatious housing narrative assumes an ongoing positive population trend for Halle. Within the next few years, the University of Halle wants to increase the number of students and promote economic development. In addition, the research site in Halle shall be developed. The historic old-town neighborhoods are already popular among young people. For this scenario, a shortage of attractive flats is assumed, which leads to a light concentration owing to new building activities and gap closures within these areas. All the transformative areas are converted into land use "Discontinuous Dense Urban Fabric" or keep this land use state.

Urban densification The category of "dense urban" was introduced by the former German Minister of Environment Barbara Hendricks in 2016. The amendment of the building law is intended to be a solution to housing shortages in urban centers. Although the final directive is still missing, some assumptions about the juridical changes and their spatial consequences can be made from the statements of the ministry. On the one hand, the "dense urban" type means to increase the potential residential areas via the weakening of the noise ordinance; thereby some commercial areas could be transformed into residential areas. On the other hand, the minimum distances between buildings shall be reduced and the maximum height of the buildings shall be extended. Both revisions will lead to an increase of urban density. For the implementation of this scenario, a new land use class "dense urban," was added to the existing built classes (Table 3).

Fig. 4. Rule-based land use change modeling using GIS-queries.

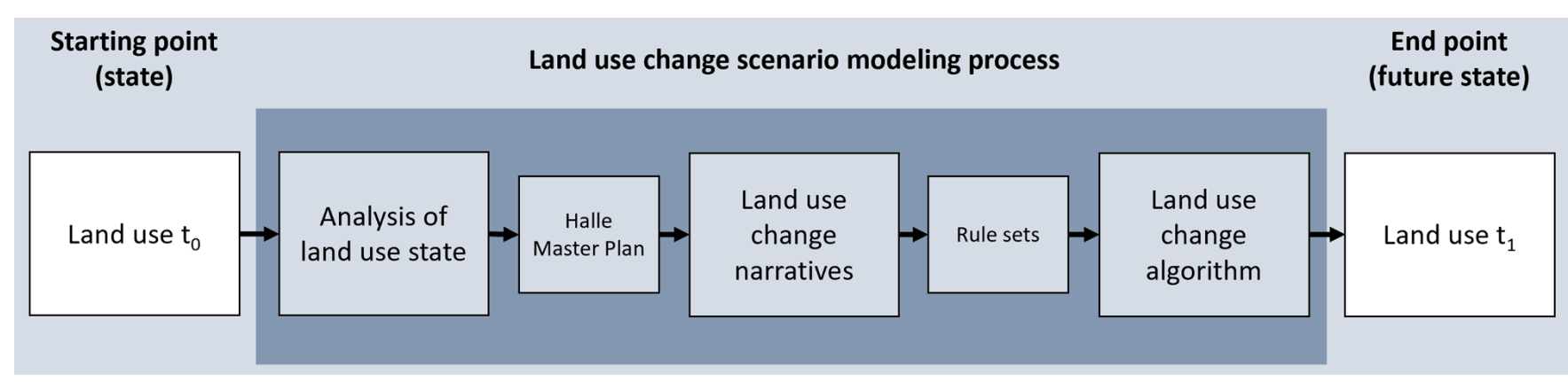


Table 3. Land use change rules.

\begin{tabular}{|c|c|c|c|}
\hline Land use $\mathrm{t}_{0}$ & Land use $t_{1}$ & Condition 1: Applies to & Condition 2: Applies to/in the \\
\hline $\begin{array}{l}\text { Land without current use } \\
\text { (brownfields) becomes }\end{array}$ & Urban gardens & $\begin{array}{l}\text { In all strategic development areas } \\
\text { such as the Southern Suburb etc. }\end{array}$ & Edible City narrative \\
\hline $\begin{array}{l}\text { Land without current use } \\
\text { (brownfields) becomes }\end{array}$ & $\begin{array}{l}\text { Discontinuous Medium Density } \\
\text { Urban Fabric; Discontinuous Low } \\
\text { Density Urban Fabric }\end{array}$ & $\begin{array}{l}50 \% \text { Medium Density } \\
50 \% \text { Low Density }\end{array}$ & Spatious Housing narrative \\
\hline Construction sites become & & $\begin{array}{l}50 \% \text { Medium Density } \\
50 \% \text { Low Density }\end{array}$ & \\
\hline $\begin{array}{l}\text { Continuous Urban Fabric (sealing }> \\
80 \% \text { ); Discontinuous Medium } \\
\text { Density Urban Fabric (sealing } 30- \\
50 \% \text { ) becomes }\end{array}$ & Urban area (new class) & $\begin{array}{l}\text { Northern Suburb } \\
\text { Southern Suburb }\end{array}$ & Urban densification narrative \\
\hline $\begin{array}{l}\text { Land without current use } \\
\text { (brownfields) becomes }\end{array}$ & $\begin{array}{l}\text { Park (public green spaces) } \\
\text { Urban gardens }\end{array}$ & $\begin{array}{l}\text { All strategic development areas such } \\
\text { as the Southern Suburb etc.; } \\
50 \% \text { each }\end{array}$ & Green City narrative \\
\hline
\end{tabular}

multiplying the number of flats roughly given by the residential morphology data (Table 1) with the average household size. Where the Master Plan focuses on greener development, we transferred existing brown/greyfields $\left(\mathrm{t}_{0}\right)$ into parks (green spaces based on the land use typology used; $\mathrm{t}_{1}$ ).

The new land use state $t_{1}$ (that of the respective narrative) was created by "translating the narratives into "if-then-else" queries' (Larondelle et al. 2016:634) that define the current land use state and its change from $t_{0}$ to $t_{1}$. The initial state $\left(t_{0}\right)$ was the land use in 2018 (in Copernicus; Fig. 4). Using the "if-then-else" conditional rules, each narrative was translated into a land use map $\left(t_{1}\right)$ for each of the six strategic development areas. A sequential scheme of a land use state change iteration is displayed in Figure 4.

Linear structures such as streets and railways were not treated within the land use change scenarios except when they were specifically mentioned in the master plan (see the method of Larondelle et al. 2016). The existing built space was not changed in the scenarios and was assumed to remain. All land use change rules developed according to the Halle Master Plan are systematically listed in Table 3.

Applying these rules for the area of interest for scenario building, the vector data maps were exported from QGIS into .csv files and processed in R and MS Excel before they were visualized using QGIS. Processing included the summary of land use types before and after the rule application for the single strategic development area and the sum of all development areas.

\section{Ecosystem service potential assessment}

To assess the environmental impact of the four development narratives for the six strategic development areas in Halle, a bundle of ES was selected and quantified for each land use class. To cover those ES mentioned in the Halle Master Plan as valuable ecosystem services for Halle residents, in line with CICES, we selected one cultural service (recreation potential; class 3.1.1.1. physical and experiential interactions with the natural environment), one provisioning service (local food production potential; class 1.1.1.1. cultivated terrestrial plants, including fungi, algae, grown for nutritional purposes), and with respect to climate change adaptation, which will be key for Halle (Huang et al. 2015), three regulating services (air cooling potential, runoff water regulation and flood prevention, and $\mathrm{CO}_{2}$ mitigation; class 2.2.1.1. regulation of baseline flows and extreme events; class 2.2.6.2. regulation of temperature and humidity, including ventilation and transpiration). To calculate the specific ES potential values, we followed empirical and lookup-table-based studies that have already been applied by Larondelle et al. (2016): (a) recreation potential (Kain et al. 2016), (b) local food production potential (Kain et al. 2016), (c) air cooling potential (Schwarz et al. 2011), (d) runoff water regulation and flood prevention potential (Nuissl et al. 2009), and (e) $\mathrm{CO}_{2}$ mitigation potential (Strohbach and Haase 2012, Larondelle and Haase 2013; Table 4). Some of the indicators we applied are binary, while others are numerical in nature. All ES indicators have one value for each land use (state), which we introduced in Table 2. Except for the study by Kain et al. (2016), all other ES studies were carried out in Central Germany, and thus, the results that these studies obtained are highly relevant for the case of Halle. All other studies except Schwarz et al. (2011) used the Urban Atlas land use/cover database, as we do in our own case. Schwarz et al. (2011) made use of Corine Land Cover (EEA), which is comparable with the Urban Atlas; thus, land use state classes could be changed for others/alternative ones.

For water regulation and flood prevention, the proxy of fast runoff was applied. In our conceptualization, fast runoff equals the surface runoff that does not enter the soil phase. It does not refer to conventional grey piping systems for stormwater/runoff. In our case, fast runoff includes the complete surface water flow, including sealed and non-sealed surfaces, according to Haase and Nuissl (2007) and Haase (2009) summarized in Nuissl et al. (2009). We argue that green and non-sealed areas can enable runoff to be removed from impervious surfaces faster, as they provide seeping surfaces directly positioned next to the grey surfaces (Haase 2009).

For the two new land use classes that we introduced, urban gardens and dense urban areas, the values for the ES calculation were defined as follows. For gardens, the values for horticulture from the Rotterdam study by Larondelle et al. (2016) were assigned. For the calculation of the food supply potential in Halle, organic cultivation with a productivity of 24 tons per hectare for 
Table 4. Performance of ecosystem services indicators for the land use states modeled.

\begin{tabular}{|c|c|c|c|c|c|}
\hline Land use & $\begin{array}{c}\text { Recreation potential } \\
\text { [binary after Kain et al. } \\
2016]\end{array}$ & $\begin{array}{c}\text { Food production } \\
\text { potential } \\
\text { [binary after Kain et al. } \\
\text { 2016] }\end{array}$ & $\begin{array}{c}\text { Air cooling [Surface } \\
\text { emissivity after Schwarz } \\
\text { et al. 2011] }\end{array}$ & $\begin{array}{l}\text { Seepage water flow } \\
\text { [when total runoff }=1 \\
\text { after Nuissl et al. 2009] }\end{array}$ & $\begin{array}{c}\mathrm{CO}_{2} \text { mitigation [in } \mathrm{tC} / \mathrm{ha} \\
\text { after Strohbach and } \\
\text { Haase 2012, Larondelle } \\
\text { and Haase 2013] }\end{array}$ \\
\hline $\begin{array}{l}\text { Continuous Urban } \\
\text { Fabric }\end{array}$ & 0 & 0 & 143.2 & 0.90 & 4.20 \\
\hline $\begin{array}{l}\text { Discontinuous Dense } \\
\text { Urban Fabric }\end{array}$ & 0 & 0 & 143.2 & 0.65 & 5.10 \\
\hline $\begin{array}{l}\text { Discontinuous } \\
\text { Medium Density } \\
\text { Urban Fabric }\end{array}$ & 0 & 0 & 139.4 & 0.40 & 20.00 \\
\hline $\begin{array}{l}\text { Discontinuous Low } \\
\text { Density Urban Fabric }\end{array}$ & 0 & 0 & 139.4 & 0.20 & 13.70 \\
\hline $\begin{array}{l}\text { Discontinuous Very } \\
\text { Low Density Urban } \\
\text { Fabric }\end{array}$ & 0 & 0 & 134.3 & 0.05 & 21.50 \\
\hline $\begin{array}{l}\text { Industrial, } \\
\text { Commercial }\end{array}$ & 0 & 0 & 141.5 & 0.80 & 8.52 \\
\hline Roads & 0 & 0 & 145.1 & 0.30 & 0.00 \\
\hline Railways & 0 & 0 & 145.1 & 0.85 & 0.00 \\
\hline Port Area & 0 & 0 & 139.9 & 0.60 & 8.52 \\
\hline Mineral extraction & 0 & 0 & 138.0 & 0.20 & 0.00 \\
\hline Construction & 0 & 0 & 138.0 & 0.30 & 0.00 \\
\hline $\begin{array}{l}\text { Without current land } \\
\text { use }\end{array}$ & 0 & 0 & 136.0 & 0.20 & 10.12 \\
\hline Green Urban Area & 1 & 0 & 134.3 & 0.10 & 29.38 \\
\hline Sport, Leisure & 1 & 0 & 138.4 & 0.10 & 5.00 \\
\hline Agriculture & 1 & 1 & 136.7 & 0.00 & 4.75 \\
\hline Forest & 1 & 0 & 132.8 & 0.00 & 72.31 \\
\hline Water & 1 & 0 & 131.3 & 0.00 & 0.00 \\
\hline Garden land & 1 & 1 & 138.9 & 0.00 & 15.00 \\
\hline Dense urban & 0 & 0 & 143.2 & 0.95 & 2.10 \\
\hline
\end{tabular}

rich loess soils (as found in Halle) was assumed. Carbon pools for $\mathrm{CO}_{2}$ mitigation were calculated with $15 \mathrm{tC} /$ ha and a surface emissivity of 138.9 , similar to the existing class of "dense continuous urban fabric" of the Urban Atlas. In gardens, we assume that soils are unsealed. Both food production and recreation are possible in these areas. In contrast, in the new dense urban areas, space is limited, and thus, neither local food production nor high-quality recreation is possible. Thus, we assigned the value of zero. The value for surface imperviousness increased by approximately $3 \%$ in dense urban areas based on studies of very compact cities such as Barcelona, Spain, or Vienna, Austria, where the soil sealing reached $90 \%$ in highdensity areas (Baró et al. 2016). For an approximation of the carbon pools and $\mathrm{CO}_{2}$ mitigation capacity, we assume that the land use class of dense urban areas is similar to "continuous urban fabric", for which Strohbach and Haase (2012) found an average carbon storage of $4.2 \mathrm{tC} / \mathrm{ha}$ in the region of Leipzig, with a standard deviation of $2.1 \mathrm{tC} / \mathrm{ha}$. The land use type "dense urban area" will most likely have fewer trees and, if so, smaller trees due to lack of sunlight, narrowness, and a poor soil state. Thus, using the value of $2.1 \mathrm{tC} /$ ha, we slightly overestimate the $\mathrm{CO}_{2}$ mitigation potential of this new urban land use type.

Available green space was interpreted as recreational space according to a review by Kabisch et al. (2015) and another European study by Kabisch et al. (2016a, b). For a straightforward display of the trade-offs and synergies between the different ES potentials, we used the popular spider graphs. This type of graph allows all ES and all scenarios to be cross-compared and the essential differences to be captured. For this purpose, the areaweighted average for each urban ES per scenario was calculated and normalized to between 0 and 1 . The example of the Southern Inner City shows how similar or, alternatively, how different the outcomes of potential land use change patterns in terms of GBIrelated ES will be and what regrowth might mean.

\section{RESULTS}

Based on the results of the land use alternative modeling, the GIS maps provide novel insights into spatially explicit neighborhood development paths for the city of Halle under regrowth as the framing master plan assumes. Overall and across all strategic development areas, the change potential of the corresponding land uses is between 8 and $20 \%$ of the total neighborhood area (Table 5). This reveals that Halle, as a formerly shrinking city, still provides a considerable amount of space for GBI increase and for enabling more access to green space throughout different parts of the city, despite the very heterogeneous spatial configuration, i.e., patch size, shape, neighboring land uses, and degree of connectivity, of this space potential. Thus, the land use alternatives tell us that the potential for enabling ES benefits differs in terms of both the overall change potential and its spatial configuration in terms of the accessibility for local residents (see the green space-residential use distribution and distance in the maps of Fig. 5) of the different ES-generating land use patches (parks, gardens, neighborhood green). The land change potential is particularly high in Halle-Newtown, a large, prefabricated 
Fig. 5. Current land use change potential outlined in the Master Plan for 2025 (ISEK), and land use states modeled for the four different narratives outlined in Table 3 (spatious housing, edible city, green city, urban densification) for the Southern Inner City district. S.L. = sealing level.

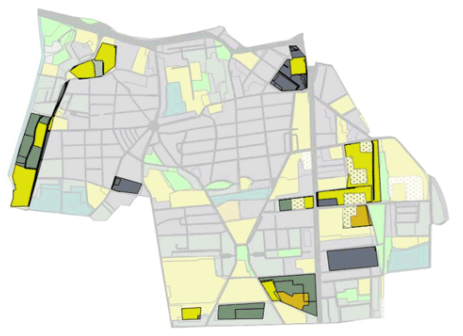

Land use 2018

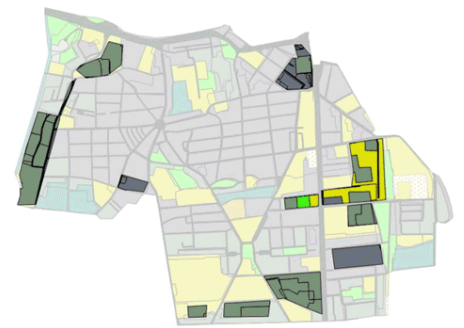

Spatious housing

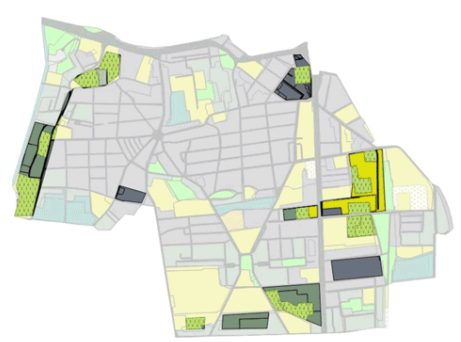

Edible city

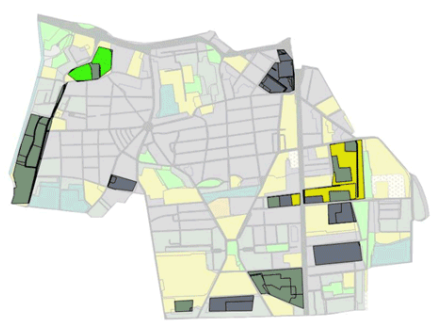

Master Plan 2025

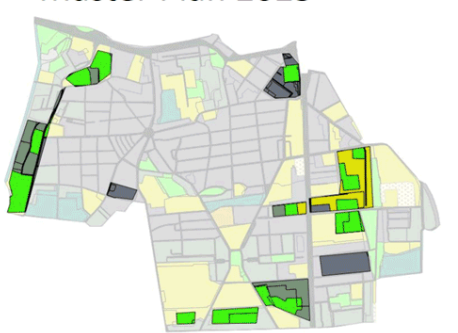

The green city

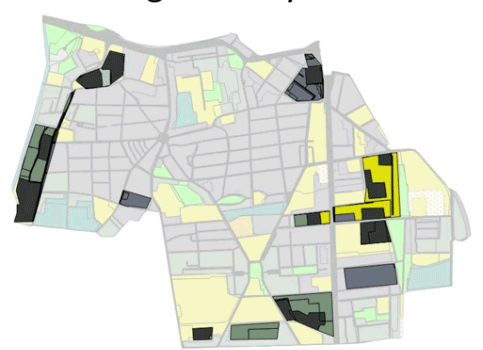

Urban densification

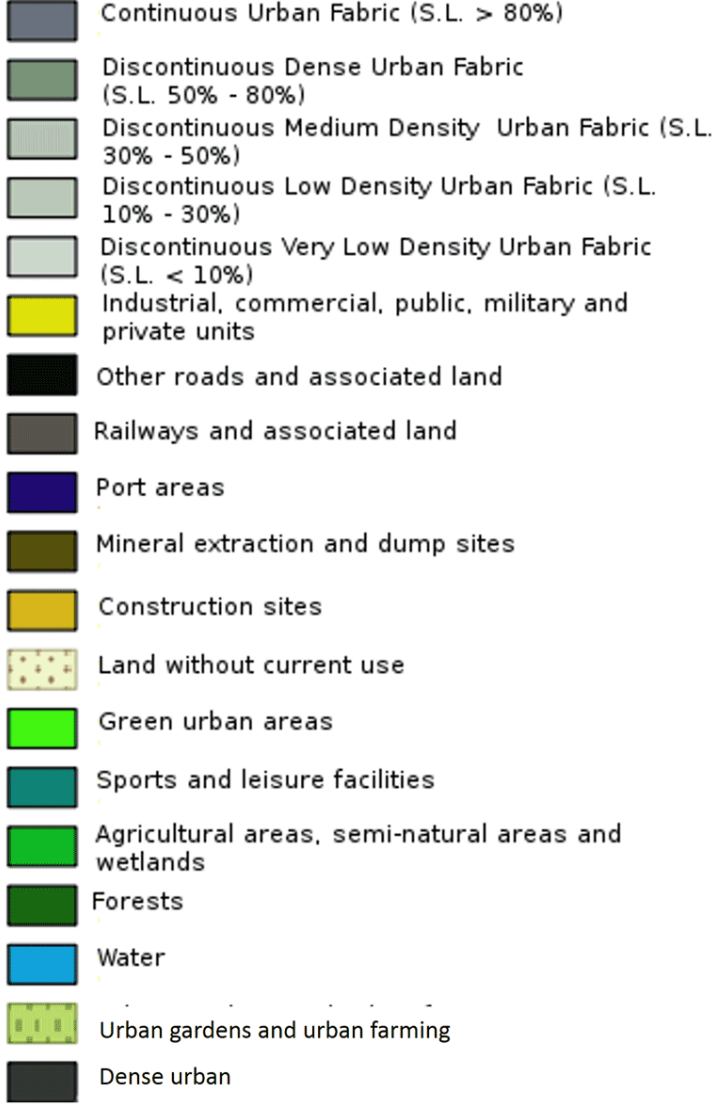

housing estate with a comparatively low amount of green spaces. Here, a larger green and gardening development potential is predominantly allocated in the north, which is characterized by higher income and more consolidated social conditions compared to the rest of Halle-Newtown.

Table 5. Total area of land change potential in the six strategic development areas.

\begin{tabular}{lcc}
\hline \hline $\begin{array}{l}\text { Neighborhood / } \\
\begin{array}{l}\text { Strategic Development } \\
\text { Area }\end{array}\end{array}$ & $\begin{array}{c}\text { Area } \\
\text { (in ha) }\end{array}$ & $\begin{array}{c}\text { Share of total city area } \\
\text { (in \%) }\end{array}$ \\
\hline Southern Inner City & 42.14 & 12.0 \\
Northern Inner City & 39.65 & 13.3 \\
Silberhöhe & 38.84 & 17.5 \\
Southern Suburb & 20.89 & 8.8 \\
Newtown & 155.54 & 20.4 \\
Heide-North & 19.25 & 8.4 \\
\hline
\end{tabular}

As is typical for old European industrialized cities (Larondelle et al. 2016, Scott et al. 2016), most of the land use transition potential can be found in out-of-use industrial and transportation areas in the inner parts of the city. As Table 6 shows, almost $50 \%$ of the entire change potential consists of brownfields, which often comprises large coherent areas that are rectangular or linear. When adding the land use class of urban brownfields to industrial and transportation land, we obtain more than $60 \%$ of the land change potential. Discontinuous urban fabric is another land use state that holds potential for change. More than $20 \%$ of all potential change occurs at the cost of low(er) density housing use. In particular, the potential for brownfields is highest in the Southern Inner City (Table 6).

For the strategic development area of Southern Inner City, a series of six maps provide a detailed view of those changes that are possible and imaginable in a city facing (still) shrinking remnants and features of regrowth (Fig. 5). This example shows that changes in green and garden uses constitute an area of approximately $12 \%$ of the whole strategic development area, which could enable essential ES potential and respective benefits such as air cooling, health support, and active recreation. In the case of the realization of the new development "urban area" type, densification limits any greening to zero and establishes a strong physical barrier to accessing neighborhood recreation and biodiversity steppingstones (Fig. 5, "urban densification"). The scenarios of both the green city and the edible city would embrace 
Table 6. Land use state change matrix for the six strategic development areas (in \% of total area of the respective strategic development area summed up for all four land use alternatives).

\begin{tabular}{|c|c|c|c|c|c|c|c|c|c|}
\hline & $\begin{array}{l}\text { Continuous } \\
\text { urban fabric }\end{array}$ & $\begin{array}{l}\text { Discontinuous } \\
\text { dense urban } \\
\text { fabric }\end{array}$ & $\begin{array}{c}\text { Discontinuous } \\
\text { medium } \\
\text { dense urban } \\
\text { fabric }\end{array}$ & $\begin{array}{c}\text { Industry, } \\
\text { commercial } \\
\text { land }\end{array}$ & Roads & $\begin{array}{l}\text { Construction } \\
\text { sites }\end{array}$ & Brown-fields & $\begin{array}{c}\text { Green urban } \\
\text { areas }\end{array}$ & $\begin{array}{c}\text { Agriculture, } \\
\text { wetlands }\end{array}$ \\
\hline$\overline{\mathrm{SIC}^{\dagger}}$ & & 2.53 & 0.52 & 8.96 & & 2.55 & 3.81 & & \\
\hline $\mathrm{NIC}^{+}$ & & & & 8.42 & & & 0.50 & & \\
\hline Silberhöhe & 0.34 & 4.10 & & 1.93 & & & & & \\
\hline Southern $\mathrm{S}^{\S}$ & 0.99 & 0.34 & & 3.86 & 0.13 & & 0.56 & & \\
\hline Newtown & & 1.9 & & 9.42 & & & 2.84 & & \\
\hline Heide-North & 0.20 & 1.35 & 1.16 & 0.79 & & & & 4.23 & 1.69 \\
\hline Sum & 1.53 & 10.53 & 1.68 & 33.38 & 0.13 & 2.55 & 7.71 & 4.23 & 1.69 \\
\hline
\end{tabular}

Southern Inner City, ${ }^{\dagger}$ Northern Inner City, ${ }^{\S}$ Southern Suburb

the densely built core area of the neighborhood and allow for new recreational space from all sides.

For the Southern Inner City, spider graphs were used (see the example in Fig. 6) to visualize the overall ES benefit potential for all strategic development areas: the current land use in 2018 (Urban Atlas data), the 2025 vision of the Halle Master Plan, and the four alternative development scenarios (Fig. 2, Table 2).

Fig. 6. Ecosystem services benefits flows calculated for all six strategic development areas, the current land use 2018, and the Master Plan vision for 2025 using spider graphs. The example shows the neighborhood of the Southern Inner City.

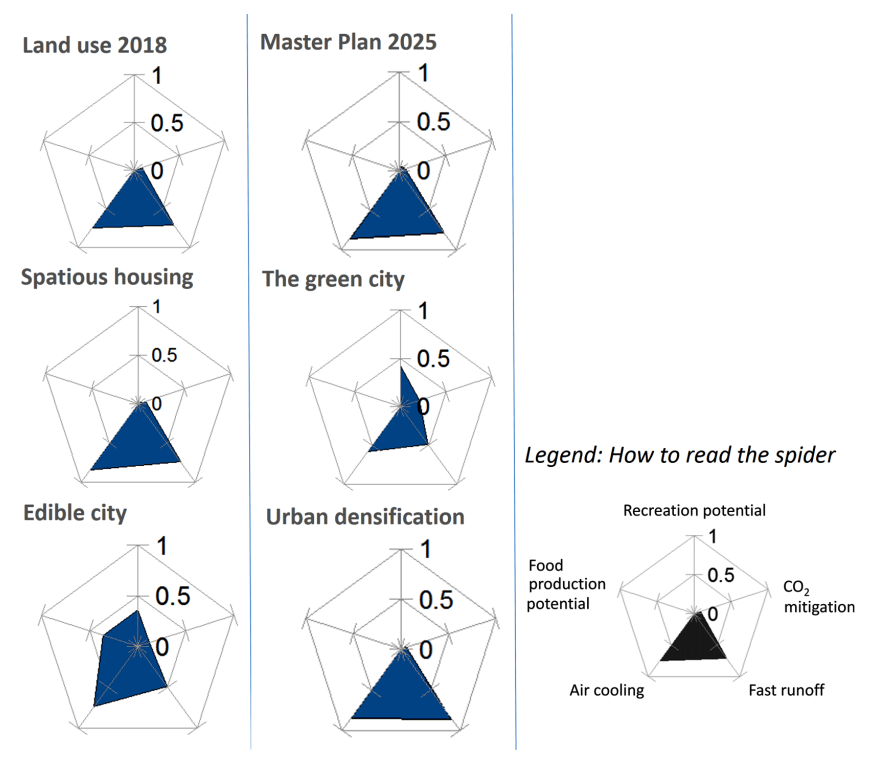

Both the green and edible city models show a more balanced spider graph that includes important ES such as air cooling by vegetation and $\mathrm{CO}_{2}$ mitigation to face climate change and urban heat/drought waves. The spider also shows trade-offs between climate regulation (proxied by carbon fixation) through tree vegetation and local food production, where $\mathrm{CO}_{2}$ fixation does not play a large role. Fast runoff cannot be regulated by highly sealed soils at present, in the master plan vision for 2025 , or in the urban densification scenario where fast superficial runoff doubles compared to the edible and green city scenarios.

In conclusion, based on the ES spider diagrams, the urban densification scenario, which is currently high on the agenda of many cities in Germany and other European countries because it allows for growth and more flats in the inner city, is the least favorable in terms of ground-based ES potential. Thus, this scenario neutralizes the benefits for people from nature because of physical infrastructure.

\section{Carbon mitigation}

Looking more closely at the selected key ES quantified in this study, we observe that $\mathrm{CO}_{2}$ mitigation potential decreases to approximately $16 \mathrm{t}$ in the scenario "ISEK 2025" for two strategic development areas, the Northern and Southern Inner-City areas, as the share of old industrial areas is foreseen for construction. Even less carbon would be stored in the urban densification scenario (green pillars in Fig. 7), but this scenario would be most responsive to housing pressure. By comparison, the green scenario shows an opportunity for increasing the carbon storage capacity by approximately $9 \%$ in the Northern Inner City, 19\% in the Southern Inner City, and approximately $15 \%$ in the prefabricated Halle-Newtown because of GBI (parks with trees and lawns) implementation (Fig. 7).

However, there is one strategic development area, Silberhöhe, where the carbon pool is massively reduced within all scenarios, which has mainly resulted in its current organization. There, tree plantations were planted after the demolition of many blocks and would be removed in all scenarios, including the green city scenario, as playgrounds and lawns/meadows will be introduced to make the area an attractive green space for people. Thus, the carbon storage loss in this district would amount to 372 tons $\mathrm{C}$ per year under the green city scenario (Fig. 7).

\section{Recreation}

Halle is a green city with enormous spatial heterogeneities in terms of per capita recreational space. At present, the inner-city districts provide $<10$ and between 20 and up to $30 \mathrm{~m}^{2}$ of available green space per resident, whereas prefabricated housing estates such as Silberhöhe or Newtown provide between 30 and $45 \mathrm{~m}^{2}$. Because of ongoing population growth, the per capita green space decreases. Following the master plan, each resident will have less than $9 \mathrm{~m}^{2}$ of public green space available within walking distance 
Fig. 7. Net carbon pool change in tons $C$ per year per scenario and strategic development area including the Master Plan vision for 2025. The land use 2018 is zeroed for reference.

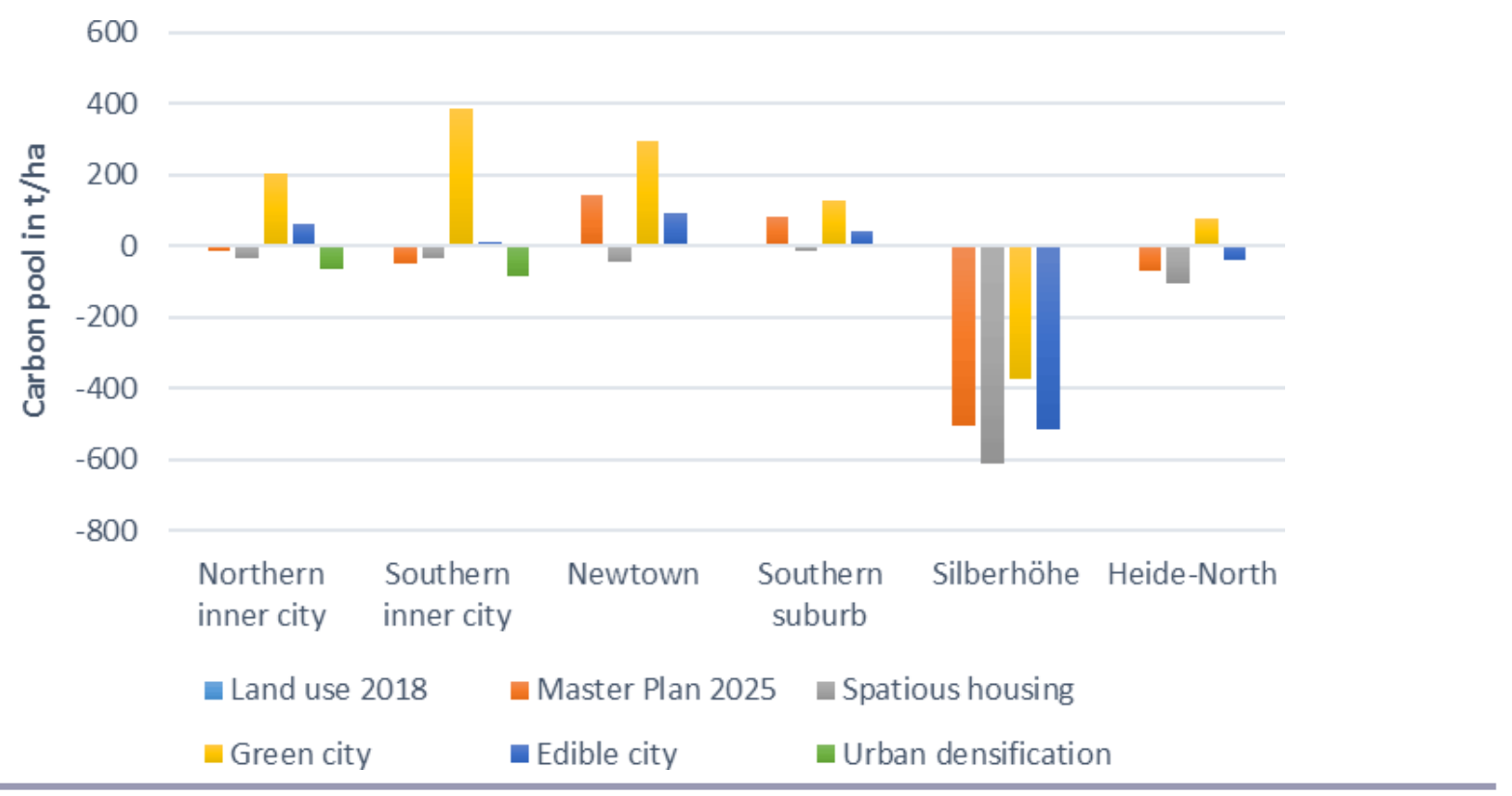

in the Southern Inner City. In the Northern Inner City, this number declines to approximately $5 \mathrm{~m}^{2}$ per person. Urban densification (urban area scenario) leads to a further decline (Fig. 8 ). Both the green and edible city scenarios offer an increase in per capita urban green space in all strategic development areas of approximately $2-10 \mathrm{~m}^{2}$, which might lead to per capita green space numbers that are 6-7 times higher those in the inner parts of Halle and even increase the existing inequality of green space distribution and the benefits that are generated at the respective green spaces.

\section{Food production in local gardens}

In the Halle Master Plan, local food production is also discussed as one option for sustainable redevelopment. With more intense organic cultivation methods and in situ humus accumulation, harvests of up to 50 tons per hectare could be obtained. Based on the model, the results show enormous potential for two strategic development areas, both the Southern Inner City and Halle-Newtown, each with a capacity of $>350 \mathrm{t}$. In the edible city scenario, total fresh fruits, and vegetable production of $1560.7 \mathrm{t}$ could be obtained by transforming potential land into urban gardens.

\section{DISCUSSION}

First, this study shows how the master planning of the city of Halle, based on assumptions of population regrowth, will alter the land use composition in the city by 2025 . The Halle Master Plan includes regrowth as one of the fundamental assumptions and future vision of and for the city. The land use alternatives in this paper have been built assuming population growth and, thus, what key papers understand about regrowth (Kabisch et al. 2010, Wolff et al. 2016, Wolff and Haase 2019). As the study by Larondelle et al. (2016) found for Rotterdam, the potentials for densification, as well as for open land use transitions, are great and are not exclusively in the outer parts of the city. As Wolff et al. (2017) found for Leipzig, and as Nelle et al. (2017) found for many Eastern German cities, the path dependency of shrinkage, disinvestment, and related population loss plus outmigration holds a high transformative potential in many parts of a city that offer greening of the inner city and a reurbanization of large-scale prefabricated housing estates.

The study further shows that the spatial transition potential is heterogeneously distributed across a city and enables a surprisingly fair implementation of new land uses, including GBI, to enhance the chances for more sustainable development (Andersson et al. 2019). For example, the conversion of industrial or transportation brownfields is a clear surplus in habitat quality and green space cohesion in case they are greened, which would be key for urban bird species such as woodpeckers or tits (Strohbach et al. 2009). What is a quite novel finding of this study is that single and detached house areas will further lose population and offer transition potential. This is in line with what Kabisch et al. (2019) report, but also what studies in other parts of Europe, such as Wolff et al. (2018) found: Since a first wave of city abandonment and single house first-time occupancies after the reunification in 1990, these peripheral low-density housing areas have continuously lost attractiveness, not only in Eastern Germany. Addressing both brownfield and low-density residential areas for change in a set of rule-based GIS models made it even clearer that a regrowing city such as Halle can offer a home for many new residents. However, there are trade-offs between unlimited population growth and the provisioning of ES. The neighborhood scale of this study can quantitatively address these trade-offs by reporting numbers that enable comparison between the effects of new residents' allocation and space for ES provisioning. 
Fig. 8. Enabling recreation potential (in $\mathrm{m}^{2}$ per capita): Per-capita green space per scenario and strategic development area including the current land use 2018 and the Master Plan vision for 2025.

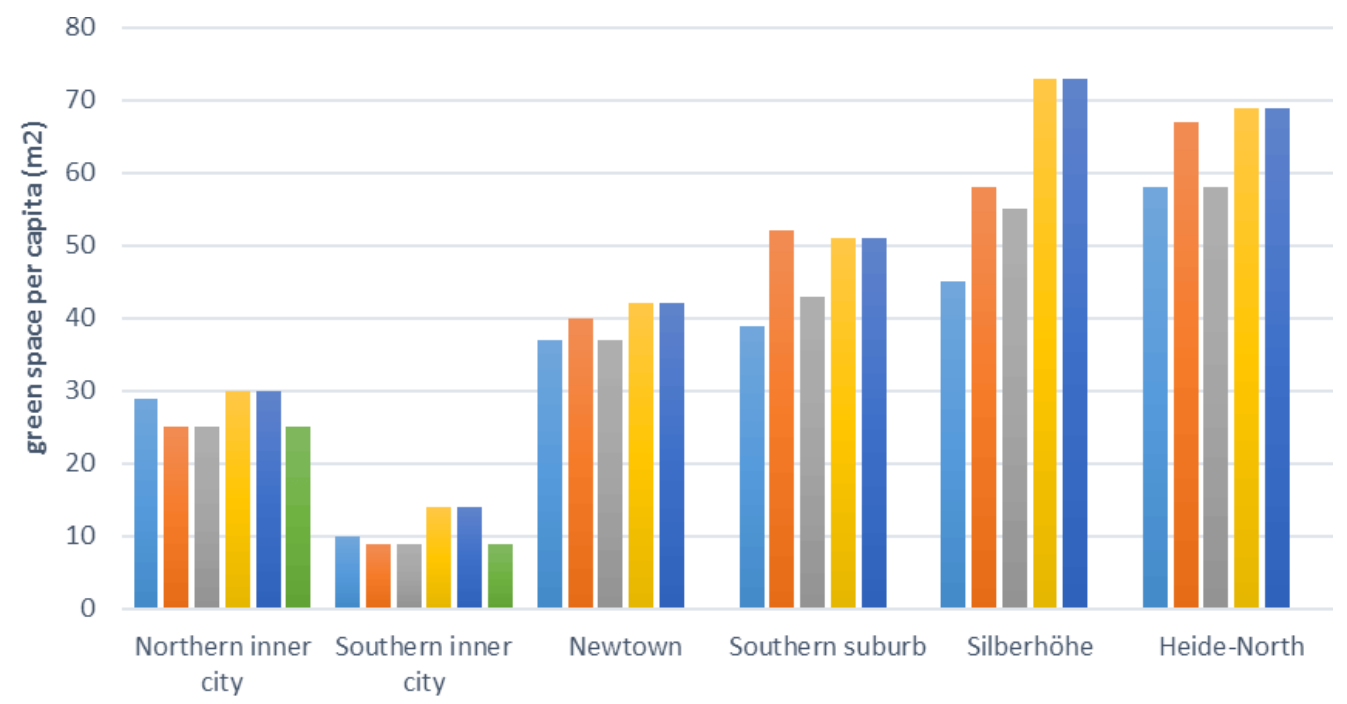

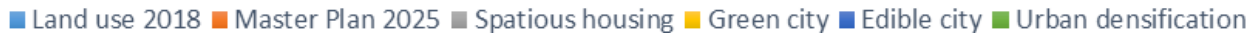

According to the Urban Agenda of the EU and the Leipzig Charter, brownfields are a particularly valuable and nonrenewable land resource; their regeneration offers the chance to mitigate the pressure on land in densifying cities. The redevelopment of brownfields must be carefully governed to prevent socio-demographic trade-offs that foster gentrification or that reinforce existing inequalities, e.g., by creating private green spaces that are not accessible to the wider public (Rink et al. 2012).

One particular result of the Halle study is that for the first time, the "dense urban" land use type introduced in 2017 (Germany Ministry for Construction and Environment) was attributed and implemented. In so-called "dense urban" areas, we assume that heat and health problems will increase based on the increase in the built density in our models and in line with other reported outcomes of densification scenarios (Kondo et al. 2018). To date, this new urban land use (density) type to a certain extent contradicts the requirements of sustainable urban development (Elmqvist et al. 2019, Wolff and Haase 2019). Tightly packed multi-story buildings prevent direct sunlight and rainwater infiltration and detract from outdoor space. The new urban area type works against meeting the climate change challenge, as highdensity cities without GBI are particularly vulnerable to extreme weather events such as heat waves or heavy rainfall (Reckien et al. 2017). This study shows that in inner city areas, additional densification will have significant negative impacts not only on carbon mitigation capacity but also, most of all, on the recreational potential provision.

The comparison of the land use change alternatives revealed an interesting and counterintuitive result, at least regarding the preferred or celebrated paradigm of the "compact city" (as argued in Nuissl et al. 2009, Westerink et al. 2013, Nilsson et al. 2014). In all cases, the ES potential values for the green and edible city scenarios far exceed those of all other narratives. We state that, first, in terms of the GBI-driven ES benefit potential, the preferred model of the compact city is insufficiently equipped with GBI (Wolff and Haase 2019). Second, both the spacious housing and urban densification narratives reported very low ES values. Therefore, although cities need to reduce their impact on nature (Nuissl et al. 2009, McDonald et al. 2020), a balance between open and built land use within cities needs to be ensured. Urban compaction at the expense of natural green and ES is not sustainable when considering all dimensions of sustainability and the declines in the per capita green space rates we could show. Third, the high ES provision values of the green and edible city narrative reveal the multi-dimensional benefits of GBI and allow us to assume although not test yet that, depending on local conditions and context, a compact-green-edible combination could maximize ES potential benefits.

This paper referred to the provision of ES under different future development alternatives including the urban densification narrative for the novel "urban area" land use type. Doing so, this study sheds light on the fact that there are synergies and tradeoffs between different ES, particularly between the two sustainable narratives, the green city and the edible city. Whereas the edible city contributes to a more sustainable supply of food and thus reduces environmental harm outside the city and the urban footprint (Thornton 2020), garden land does not make it possible to foster $\mathrm{CO}_{2}$ mitigation because of missing trees for carbon uptake and saving. The transitions of an afforested neighborhood into urban garden land imply immense carbon release. Thus, tree-based GBI and the promotion of urban gardening need to be thoroughly reflected in terms of the ecosystem effects before implementation. However, in most master plans for formerly shrinking cities and towns in Eastern Germany studied by authors (e.g. Leipzig, Chemnitz, Gera, 
Magdeburg to list an important few; Zabel and Kwon 2021), neither synergies nor trade-offs between food production and tree-based regulatory ES are adequately addressed. Consequently, the plans are hardly able to realize the difference between the pure creation of GBI and the strategic development of embedded, high-quality green space providing different ES, as this study uncovered.

Following Andersson et al. (2021, in this Special Feature), the ES potential that was modeled in this study should be understood as capacity for realizing the respective GBI benefits provided by the land use alternatives. The six narratives developed provide a differentiated picture of the various possible impacts of urban regrowth on the provision of GBI benefits, and have also revealed how greening can balance and foster existing inequalities in per capita green space availability (as Kabisch and Haase 2013 and Wolff and Haase 2019, found at the European scale for many cities). In addition, population regrowth and the consequent construction/re-densification, particularly in the inner parts of cities, cannot be compensated for by additional green space according to our model; thus, they lead to a loss of (already limited) ES provision, particularly for recreational services. These factors will also limit the contribution of GBI to the public health and well-being of the residents in these neighborhoods (Westerink et al. 2013). In terms of heat, air cooling could additionally benefit in all construction scenarios from a shade surplus due to the decreasing areas of direct insolation and the increase in building shade from multi-story buildings as novel studies suggest (Alavipanah et al. 2018, Park et al. 2021).

The applied model further allows a spatially differentiated perspective on the variation in the described impact on different neighborhoods - in our case, six strategic development areas - in Halle. When looking at the prefabricated large-scale housing estates built in the socialist era, such as Newtown or Silberhöhe, we note that a certain path dependency of the former shrinking and depopulation process is obvious (Wolff et al. 2017). These neighborhoods are green and already today provide higher per capita green space numbers than the best (green) land use alternative can create for inner-city development areas. This high amount of green space could be used as a complementary strategy in addition to providing affordable housing conditions to stabilize the population numbers within these formerly shrinking districts (Grossmann and Haase 2016).

The modeling results show that changes in green and garden uses constitute an area of approximately $12 \%$ of the total strategic development area, which could enable essential ES and respective benefits such as air cooling, health support, and active recreation. In the case of the realization of the new development "urban area" type, densification limits any greening to zero and establishes a strong physical barrier to accessing neighborhood recreation and biodiversity stepping stones. Both the green city and the edible city scenarios would embrace the densely built core area of the neighborhood and allow for new recreational space from all sides.

Because this modeling study relies on data and empirical knowledge, the uncertainties and explanatory power of the methods used need to be discussed and critically revisited. The main aim of this study was to quantitatively translate land use visions for a formerly shrinking and now regrowing city into GIS rules that enable change detection mapping. Using a GIS is highly appropriate for such rule-based land use change modeling, as data can be quickly and practically obtained (Ligtenberg et al. 2001, Barredo et al. 2003, Koomen et al. 2008, Lauf et al. 2012a, b, 2014, 2016 for Berlin and Leipzig, Larondelle et al. 2016 for Rotterdam). Although more precise spatial data are always advantageous, the resolution of the Urban Atlas-OSM land use class combination was satisfactory and has the clear advantage of making the study transferable to other European cities that show similar dynamics (Haase et al. 2013, Wolff et al. 2018). For a more detailed examination of neighborhood analysis, a higher resolution will be needed.

This paper modeled the potential changes of the city's vision for 2025 because the central planning document, the Halle Master Plan ISEK, does not provide detailed project descriptions on how to realize and implement its objectives. The land use alternatives calculated in this study can be tested concerning the replicability either by detailed planning within the strategic development areas or simply by what will happen. Finally, the ES quantification models were developed and tested in other case studies and could not be validated for the Halle case despite being empirically measured in neighboring cities. This aspect is both a clear disadvantage and an advantage because the study could be realized within a minimal budget.

Compared to a classical cellular automaton (Lauf et al. 2012a, b), the rule-based land use alternatives developed in this study refer to explicit land use patches that, in most cases, represent homogeneous units in terms of prevailing land use and, in almost all cases, either land ownership or stewardship types. This nonpixel type of spatial delineation of the model units presents one way to limit errors in the land change modeling process following a ground-breaking conceptual study by Pontius et al. (2011). The land use alternatives applied here include diverse, and even competing, perspectives in a set of coherent stories that were found sufficiently dissimilar to show contrasting impacts and trade-offs in ES provision (McKenzie et al. 2012).

\section{CONCLUSIONS}

Land use alternatives provide interesting and novel insights at a detailed level in terms of how to ensure both the availability and functionality of GBI and its ES capacities, in other words potential flows, for residents with increasing density. We show that the compaction of neighborhoods, in line with the paradigm of the compact city (Westerink et al. 2013), will occur at the expense of green spaces. This finding further shows that the newly introduced "urban area" land use category is not a sustainable answer to inner-city-oriented urban growth and in-migration. Important ES potentials were found to be constrained by the basic features (building density, the distance between buildings) of this type of residential area. Without further GBI measures such as green roofs/walls or semi-permeable surfaces, the well-being of residents will be negatively affected, as recreation close to home will be impossible. We can further state that the master plan failed, particularly in the Silberhöhe strategic development area, whereas in the Southern Inner City, it performed quite well for the majority of ES studied.

The narrative-based land use alternative technique applying land use change rules implemented in a GIS was found to be a straightforward way to visualize visions for urban development. 
Such visualization can be used by city and neighborhood planners to (a) develop new and (b) disseminate existing changes in the urban structure/land use to a wider public and the cities' residents. Narrative-based land use alternatives help to explore possible futures outside of previous assumptions, to initiate or deepen system understanding about land use and ES produced by nature (Thompson et al. 2020), and, this way, both the maps and the numbers created support long-term planning in a city that was raised again from shrinkage. Moreover, the land use alternatives presented enabled certain land use combinations to be identified as barriers for ES provisioning that need to be reduced or bypassed to move toward fairer GBI-induced ES benefits, which is key knowledge for actors of the urban civil society.

Finally, novel land use designs in already built spaces implementing GBI as nature-based solutions (sensu Nesshöver et al. 2017 and Frantzeskaki et al. 2019) that make cities more livable, fair, and sustainable are shown to be effective and straightforward. Methodically, spatially explicit land use scenarios are also shown to be a proper way to visualize the effects of ES benefits generated by GBI for people to be used and implemented in Halle's future open-space and neighborhood planning.

Responses to this article can be read online at: https://www.ecologyandsociety.org/issues/responses. $\mathrm{php} / 12988$

\section{Author Contributions:}

The authors state that there is no conflict of interest and all results were developed in a fair and common way.

\section{Acknowledgments:}

We warmly thank Lisa Drukewitz for supporting the writing of this article with selected data she developed during her Master's thesis at the Geographical Institute at the Humboldt University Berlin. This research was carried out, partly, as part of the project ENABLE, funded through the 2015-2016 BiodivERSA COFUND call for research proposals, with the national funders The Swedish Research Council for Environment, Agricultural Sciences, and Spatial Planning, Swedish Environmental Protection Agency, German Aeronautics and Space Research Centre, National Science Centre (Poland), The Research Council of Norway, and the Spanish Ministry of Economy and Competitiveness. In addition, this paper also presents the results of research conducted within the EU Horizon 2020 project CONNECTING Nature-COproductioN with NaturE for City Transitioning, Innovation and Governance (Project Number: 730222).

\section{Data Availability:}

Datalcode derived from public domain resources: The datalcode that support the findings of this study are available at https:/lland. copernicus. eullocallurban-atlas. These datalcode were derived from the following resources available in the public domain: Halle Land Use by Urban Atlas 2012, 2018.

\section{LITERATURE CITED}

Aalborg Charter. 1994. Charter of European Cities \& Towns Towards Sustainability. European Conference on Sustainable Cities \& Towns in Aalborg, Denmark. [online] URL: https:// sustainablecities.eu/fileadmin/repository/Aalborg Charter/ Aalborg_Charter_English.pdf

Alavipanah, S., J. Schreyer, D. Haase, T. Lakes, and S. Qureshi. 2018. The effect of multi-dimensional indicators on urban thermal conditions. Journal of Cleaner Production 177:115-123. https://doi.org/10.1016/j.jclepro.2017.12.187

Andersson, E., S. Borgström, D. Haase, J. Langemeyer, A. Mascarenhas, T. McPhearson, M. Wolff, E. Laszkiewicz, J. Kronenberg, D. N. Barton, and P. Herreros-Cantis. 2021. A context-sensitive systems approach for understanding and enabling ecosystem service realization in cities. Ecology and Society 26(2):35. https://doi.org/10.5751/ES-12411-260235

Andersson, E., J. Langemeyer, S. Borgström, T. McPhearson, D. Haase, J. Kronenberg, D. N. Barton, M. Davis, S. Naumann, L. Röschel, and F. Baró. 2019. Enabling green and blue infrastructure to improve contributions to human well-being and equity in urban systems. BioScience 69:566-574. https://doi. org/10.1093/biosci/biz058

Anguelovski, I., A. L. Brand, J. J. T. Connolly, E. Corbera, P. Kotsila, J. Steil, M. Garcia-Lamarca, M. Triguero-Mas, H. Cole, F. Baró, et al. 2020. Expanding the boundaries of justice in urban greening scholarship: toward an emancipatory, antisubordination, intersectional, and relational approach. Annals of the American Association of Geographers 110:1743-1769. https://doi. org/10.1080/24694452.2020.1740579

Arnold, J., J. Kleemann, and C. Fürst. 2018. A differentiated spatial assessment of urban ecosystem services based on land use data in Halle, Germany. Land 7(3):101. https://doi.org/10.3390/ land 7030101

Baró, F., I. Palomo, G. Zulian, P. Vizcaino, D. Haase, and E. Gómez-Baggethun. 2016. Mapping ecosystem service capacity, flow and demand for landscape and urban planning: a case study in the Barcelona metropolitan region. Land Use Policy 57:405-417. https://doi.org/10.1016/j.landusepol.2016.06.006

Barredo, J. I., M. Kasanko, N. McCormick, and C. Lavalle. 2003. Modelling dynamic spatial processes: simulation of urban future scenarios through cellular automata. Landscape and Urban Planning 64(3):145-160. https://doi.org/10.1016/S0169-2046(02) $\underline{00218-9}$

Bartholomae, F., C. W. Nam, and A. Schoenberg. 2017. Urban shrinkage and resurgence in Germany. Urban Studies 54(12) 2701-2718. https://doi.org/10.1177/0042098016657780

Draus, P., D. Haase, J. Napieralski, S. Qureshi, and J. Roddy. 2021. Lurking in the bushes: informality, illicit activity and transitional green space in Berlin and Detroit. Cultural Geographies 28:319-339. https://doi.org/10.1177\%2F1474474020948876

Elmqvist, T., E. Andersson, N. Frantzeskaki, T. McPhearson, P. Olsson, O. Gaffney, K. Takeuchi, and C. Folke. 2019. Sustainability and resilience for transformation in the urban century. Nature Sustainability 2:267-273. https://doi.org/10.1038/ s41893-019-0250-1. 
Felipe-Lucia, M. R., B. Martín-López, S. Lavorel, L. BerraqueroDíaz, J. Escalera-Reyes, and F. A. Comín. 2015. Ecosystem services flows: why stakeholders' power relationships matter. PLoS ONE 10(7):e0132232. https://doi.org/10.1371/journal. pone. 0132232

Frantzeskaki, N., T. McPhearson, M. J. Collier, D. Kendal, H. Bulkeley, A. Dumitru, C. Walsh, K. Noble, E. van Wyk, C. Ordóñez, C. Oke, and L. Pintér. 2019. Nature-based solutions for urban climate change adaptation: linking science, policy, and practice communities for evidence-based decision-making. BioScience 69(6):455-466. https://doi.org/10.1093/biosci/biz042

Grossmann, K., and A. Haase. 2016. Neighborhood change beyond clear storylines: what can assemblage and complexity theories contribute to understandings of seemingly paradoxical neighborhood development? Urban Geography 37(5):1-21. https://doi.org/10.1080/02723638.2015.1113807

Haase, A., M. Bernt, K. Grossmann, V. Mykhnenko, and D. Rink. 2016. Varieties of shrinkage in European cities. European Urban and Regional Studies 23(1):86-102. https://doi.org/10.1177/0969$\underline{776413481985}$

Haase, D. 2009. Effects of urbanisation on the water balance a long-term trajectory. Environment Impact Assessment Review 29:211-219. https://doi.org/10.1016/j.eiar.2009.01.002

Haase, D. 2013. Shrinking cities, biodiversity and ecosystem services. Pages 253-274 in T. Elmqvist, M. Fragkias, J. Goodness, B. Güneralp, P. J. Marcotullio, R. I. McDonald, S. Parnell, M. Schewenius, M. Sendstad, K. C. Seto, and C. Wilkinson, editors. Urbanization, biodiversity and ecosystem services: challenges and opportunities: a global assessment. Springer, Dordrecht, The Netherlands. https://doi.org/10.1007/978-94-007-7088-1 12

Haase, D., B. Güneralp, B. Dahiya, X. Bai, and T. Elmqvist. 2018. Global urbanization: perspectives and trends. Pages 19-44 in T. Elmqvist, X. Bai, N. Frantzeskaki, C. Griffith, D. Maddox, T. McPhearson, S. Parnell, P. Romero-Lankao, D. Simon, and M. Watkins, editors. Urban planet: knowledge towards sustainable cities. Cambridge University Press, Cambridge, UK.

Haase, D., A. Haase, and D. Rink. 2014a. Conceptualizing the nexus between urban shrinkage and ecosystem services. Landscape and Urban Planning 132:159-169. https://doi. org/10.1016/j.landurbplan.2014.09.003

Haase, D., N. Kabisch, and A. Haase. 2013. Endless urban growth? On the mismatch of population, household and urban land area growth and its effects on the urban debate. PLoS ONE 8(6):e66531. https://doi.org/10.1371/journal.pone.0066531

Haase D., A. Haase, N. Kabisch, S. Kabisch, and D. Rink. 2012. Actors and factors in land use simulation - the challenge of urban shrinkage. Environmental Modelling and Software 35:92-103. https://doi.org/10.1016/j.envsoft.2012.02.012

Haase, D., N. Larondelle, E. Andersson, M. Artmann, S. Borgström, J. Breuste, E. Gomez-Baggethun, A. Gren, Z. Hamstead, R. Hansen, N. Kabisch, P. Kremer, J. Langemeyer, E. L. Rall, T. McPhearson, S. Pauleit, S. Qureshi, N. Schwarz, A. Voigt, D. Wurster, and T. Elmqvist. 2014b. A quantitative review of urban ecosystem services assessment: concepts, models, and implementation. Ambio 43(4):413-433. https://doi.org/10.1007/ $\underline{\text { s13280-014-0504-0 }}$
Haase, D., and H. Nuissl. 2007. Does urban sprawl drive changes in the water balance and policy? The case of Leipzig (Germany) 1870-2003. Landscape and Urban Planning 80:1-13. https://doi. org/10.1016/j.landurbplan.2006.03.011

Haines-Young, R., and M. Potschin. 2010. The links between biodiversity, ecosystem services and human well-being. Pages 110-139 in D. Raffaelli and C. Frid, editors. Ecosystem ecology: a new synthesis. Cambridge University Press, Cambridge, UK. https://doi.org/10.1017/CBO9780511750458.007

Huang, S., V. Krysanova, and F. Hattermann. 2015. Projections of climate change impacts on floods and droughts in Germany using an ensemble of climate change scenarios. Regional Environmental Change 15:461-473. https://doi.org/10.1007/ s10113-014-0606-Z

ISEK Master Plan of Halle. 2016. Integrierte Stadtentwicklungsplanung - eine Vision für unsere Stadt. ISEK Master Plan of Halle, Germany. [online] URL: http://www.halle.de/de/Verwaltung/ Stadtentwicklung/ISEK-Halle-2025/Integriertes-Stadten-07744/

Kabisch, N., and D. Haase. 2013. Green space of European cities revisited for 1990-2006. Landscape and Urban Planning 110:113-122. http://dx.doi.org/10.1016/j.landurbplan.2012.10.017

Kabisch, N., D. Haase, and M. Annerstedt van den Bosch. 2016a. Adding natural spaces to social indicators of intra-urban health inequalities among children: a case study from Berlin, Germany. International Journal of Environmental Research and Public Health 13:783. https://doi.org/10.3390/ijerph13080783

Kabisch, N., D. Haase, and A. Haase. 2010. Evolving reurbanisation? Spatio-temporal dynamics exemplified by the eastern German city of Leipzig. Urban Studies 47(5):967-990. https://doi.org/10.1177/0042098009353072

Kabisch, N., D. Haase, and A. Haase. 2019. Reurbanisation: a long-term process or a short-term stage? Population, Space and Place 25(8):e2266. https://doi.org/10.1002/psp.2266

Kabisch, N., and R. Kraemer. 2020. Physical activity patterns in two differently characterised urban parks under conditions of summer heat. Environmental Science \& Policy 107:56-65. https:// doi.org/10.1016/J.ENVSCI.2020.02.008

Kabisch, N., S. Qureshi, and D. Haase. 2015. Humanenvironment interactions in urban green spaces - a systematic review of contemporary issues and prospects for future research. Environmental Impact Assessment Review 50:25-34. https://doi. org/10.1016/j.eiar.2014.08.007

Kabisch, N., M. Strohbach, D. Haase, and J. Kronenberg. 2016b. Green space availability in European cities. Ecological Indicators 70:586-596. https://doi.org/10.1016/j.ecolind.2016.02.029

Kain, J. H., N. Larondelle, D. Haase, D. Rodríguez Rodríguez, and A. Kaczorowska. 2016. Exploring local consequences of two land-use alternatives for the supply of urban ecosystem services in Stockholm year 2050. Ecological Indicators 70:615-629. https://doi.org/10.1016/j.ecolind.2016.02.062.

Kondo, M. C., J. M. Fluehr, T. McKeon, and C. C. Branas. 2018. Urban green space and its impact on human health. International Journal of Environmental Research and Public Health 15(3):445. https://doi.org/10.3390/ijerph15030445 
Koomen, E., P. Rietveld, and T. de Nijs. 2008. Modelling landuse change for spatial planning support. Annals of Regional Science 42:1-10. https://doi.org/10.1007/s00168-007-0155-1

Kroll, F., and D. Haase. 2010. Does demographic change affect land use patterns? A case study from Germany. Land Use Policy 27:726-737 https://doi.org/10.1016/i.landusepol.2009.10.001

Langemeyer, J., and J. J. T. Connolly. 2020. Weaving notions of justice into urban ecosystem services research and practice. Environmental Science \& Policy 109:1-14. http://dx.doi. org/10.1016/j.envsci.2020.03.021

Larondelle, N., N. Frantzeskaki, and D. Haase. 2016. Mapping transition potential with stakeholder and policy-driven scenarios in Rotterdam City. Ecological Indicators 70:630-643. https://doi. org/10.1016/j.ecolind.2016.02.028

Larondelle, N., and D. Haase. 2013. Urban ecosystem services assessment along a rural-urban gradient: a cross-analysis of European cities. Ecological Indicators 29:179-190. https://doi. org/10.1016/j.ecolind.2012.12.022

Lauf, S., D. Haase, P. Hostert, T. Lakes, and B. Kleinschmit. 2012a. Uncovering land-use dynamics driven by human decisionmaking - a combined model approach using cellular automata and system dynamics. Environmental Modelling and Software 27-28:71-82 https://doi.org/10.1016/j.envsoft.2011.09.005

Lauf, S., D. Haase, and B. Kleinschmit. 2014. Linkages between ecosystem services provisioning, urban growth and shrinkagea modeling approach assessing ecosystem service trade-offs. Ecological Indicators 42:73-94. https://doi.org/10.1016/j. ecolind.2014.01.028

Lauf, S., D. Haase, and B. Kleinschmit. 2016. The effects of growth, shrinkage, population aging, and preference shifts on urban development - a spatial scenario analysis of Berlin, Germany. Land Use Policy 52:240-254. https://doi.org/10.1016/j. landusepol.2015.12.017

Lauf, S., D. Haase, R. Seppelt, and N. Schwarz. 2012b. Simulating demography and housing demand in an urban region under scenarios of growth and shrinkage. Environment and Planning B: Urban Analytics and City Science 39(2):229-246. https://doi. org/10.1068/b36046t

Leipzig Charter. 2007/2020. The Leipzig Charter: basis for integrated urban development. [online] URL: https://www. nationale-stadtentwicklungspolitik.de/NSPWeb/EN/Initiative/LeipzigCharter/leipzig-charter node.html

Ligtenberg, A., A. K. Bregt, and R. van Lammeren. 2001. Multiactor-based land use modelling: spatial planning using agents. Landscape and Urban Planning 56(1-2):21-33. https://doi. org/10.1016/S0169-2046(01)00162-1

Lin, B., A. Ossola, M. Alberti, E. Andersson, X. Bai, C. Dobbs, T. Elmqvist, K. L. Evans, N. Frantzeskaki, R. Fuller, K. J. Gaston, D. Haase, C. Jim, C. Konijnendijk, H. Nagendra, J. Niemelä, T. McPhearson, W. R. Moomaw, S. Parnell, D. Pataki, W. J. Ripple, and P. Y. Tan. 2021. Integrating solutions to adapt cities for climate change. Lancet Planet Health 5:e479-e486. https://doi. org/10.1016/S2542-5196(21)00135-2

McDonald, R., A. V. Mansur, F. Ascensão, M. Colbert, K. Crossman, T. Elmqvist, A. Gonzalez, B. Güneralp, D. Haase, M.
Hamann, et al. 2020. Research gaps in knowledge of the impact of urban growth on biodiversity. Nature Sustainability 3:16-24. https://doi.org/10.1038/s41893-019-0436-6

McKenzie, E., A. Rosenthal, J. Bernhardt, E. Girvetz, K. Kovacs, N. Olwero, and J. Toft. 2012. Developing scenarios to assess ecosystem service tradeoffs. World Wildlife Fund, Washington, D.C., USA. [online] URL: https://www.worldwildlife.org/ publications/developing-scenarios-to-assess-ecosystem-service-tradeoffs

McPhearson, T., S. T. A. Pickett, N. B. Grimm, J. Niemelä, M. Alberti, T. Elmqvist, C. Weber, D. Haase, J. Breuste, and S. Qureshi. 2016. Advancing urban ecology toward a science of cities. BioScience 66(3):198-212. https://doi:10.1093/biosci/ $\underline{\text { biw002 }}$

Nelle, A., K. Großmann, D. Haase, S. Kabisch, D. Rink, and M. Wolf. 2017. Urban shrinkage in Germany: an entangled web of condition, discourse and policy. Cities 69:116-123. http://dx.doi. org/10.1016/j.cities.2017.02.006

Nesshöver, C., T. Assmuth, K. N. Irvine, G. M. Rusch, K. A. Waylen, B. Delbaere, D. Haase, L. Jones-Walter, H. Keune, E. Kovacs, K. Krauze, M. Külvik, F. Rey, J. van Dijk, O. Inge Vistad, M. E. Wilkinson, and H. Wittmer. 2017. The science, policy and practice of nature-based solutions: an interdisciplinary perspective. Science of The Total Environment 579:1215-1227. http://dx.doi.org/10.1016/j.scitotenv.2016.11.106

Nilsson, K., T. S. Nielsen, C. Aalbers, S. Bell, B. Boitier, J. P. Chery, C. Fertner, M. Groschowski, D. Haase, W. Loibl, and I. Zasada. 2014. Strategies for sustainable urban development and urbanrural linkages. Research brief. European Journal of Spatial Development.

Nuissl, H., D. Haase, M. Lanzendorf, and H. Wittmer. 2009. Environmental impact assessment of urban land use transitions -a context-sensitive approach. Land Use Policy 26(2):414-424 https://doi.org/10.1016/j.landusepol.2008.05.006

Pallagst, K., T. Wiechmann, and C. Martinez-Fernandez. 2013. Shrinking cities. Routledge, New York, New York, USA. https:// doi.org/10.4324/9780203597255

Park, J., J.-H. Kim, W. Sohn, and D.-K. Lee. 2021. Urban cooling factors: do small greenspaces outperform building shade in mitigating urban heat island intensity? Urban Forestry \& Urban Greening 64:127256. https://doi.org/10.1016/j.ufug.2021.127256

Pauleit, S., B. Ambrose-Oji, E. Andersson, B. Anton, A. Buijs, D. Haase, B. Elands, R. Hansen, I. Kowarik, J. Kronenberg, T. Mattijssen, A. S. Olafsson, E. Rall, A. P. N. van der Jagt, and C. K. van den Bosch. 2019. Advancing urban green infrastructure in Europe: outcomes and reflections from the GREEN SURGE project. Urban Forestry \& Urban Greening. 40:4-16. https://doi. org/10.1016/j.ufug.2018.10.006

Pontius Jr, R. G., S. Peethambaram, and J. C. Castella. 2011. Comparison of three maps at multiple resolutions: a case study of land change simulation in Cho Don District, Vietnam. Annals of the Association of American Geographers 101:45-62 https:// doi.org/10.1080/00045608.2010.517742

Reckien, D., F. Creutzig, B. Fernandez, S. Lwasa, M. TovarRestrepo, D. McEvoy, and D. Satterthwaite. 2017. Climate change, equity and the Sustainable Development Goals: an urban 
perspective. Environment and Urbanization 29(1):159-182. https://doi.org/10.1177/0956247816677778

Rink, D., A. Haase, M. Bernt, T. Arndt, and J. Ludwig. 2010. Urban shrinkage in Leipzig and Halle, the Leipzig-Halle urban region, Germany. Research report. European Commission, Brussels, Belgium. [online] URL: https://www.ufz.de/export/ data/400/39014 WP2 report Leipzig Halle kompr.pdf

Rink, D., A. Haase, K. Grossmann, C. Couch, and M. Cocks. 2012. From long-term shrinkage to re-growth? The urban development trajectories of Liverpool and Leipzig. Built Environment 38:162-178. https://doi.org/10.2148/benv.38.2.162

Schetke, S., D. Haase, and T. Kötter. 2012. Towards sustainable settlement growth: a new multi-criteria assessment for implementing environmental targets into strategic urban planning. Environmental Impact Assessment Review 32:195-210 https://doi.org/10.1016/j.eiar.2011.08.008

Schetke, S., D. Haase, and J. Breuste. 2010. Green space functionality under conditions of uneven urban land use development. Journal of Land Use Science 5(2):143-158 https:// doi.org/10.1080/1747423X.2010.481081

Schwarz, N., A. Bauer, and D. Haase. 2011. Assessing climate impacts of planning policies - an estimation for the urban region of Leipzig (Germany). Environmental Impact Assessment Review 31(2):97-111. https://doi.org/10.1016/j.eiar.2010.02.002

Scott, M., M. Lennon, D. Haase, A. Kazmierczak, G. Clabby, and T. Beatley. 2016. Nature-based solutions for the contemporary city/Re-naturing the city/Reflections on urban landscapes, ecosystems services and nature-based solutions in cities/Multifunctional green infrastructure and climate change adaptation: brownfield greening as an adaptation strategy for vulnerable communities?/Delivering green infrastructure through planning: insights from practice in Fingal, Ireland/Planning for biophilic cities: from theory to practice. Planning Theory \& Practice 17(2):267-300. https://doi.org/10.1080/14649357.2016.1158907

Spilková, J., and J. Vágner. 2016. The loss of land devoted to allotment gardening: the context of the contrasting pressures of urban planning, public and private interests in Prague, Czechia. Land Use Policy 52:232-239 https://doi.org/10.1016/j.

landusepol.2015.12.031

Strohbach, M. W., and D. Haase. 2012. Above-ground carbon storage by urban trees in Leipzig, Germany: analysis of patterns in a European city. Landscape and Urban Planning 104 (1):95-104. https://doi.org/10.1016/j.landurbplan.2011.10.001

Strohbach, M. W., D. Haase, and N. Kabisch. 2009. Birds and the city: urban biodiversity, land use, and socioeconomics. Ecology and Society 14(2):31. https://doi.org/10.5751/ES-03141-140231

Thompson, J. R., J. S. Plisinski, K. Fallon Lambert, M. J. Duveneck, L. Morreale, M. McBride, M. G. MacLean, M. Weiss, and L. Lee. 2020. Spatial simulation of codesigned land cover change scenarios in New England: alternative futures and their consequences for conservation priorities. Earth's Future 8(7): e2019EF001348. https://doi.org/10.1029/2019EF001348

Thornton, A., editor. 2020. Urban food democracy and governance in north and south. International Political Economy
Series. Palgrave MacMillan, Cham, Switzerland. https://doi. org/10.1007/978-3-030-17187-2

Turok, I., and V. Mykhnenko. 2007. The trajectories of European cities, 1960-2005. Cities 24(3):165-182. https://doi.org/10.1016/j. cities.2007.01.007

United Nations. 2019. World population prospects 2019. Department of Economic and Social Affairs, Population Division, United Nations, New York, New York, USA. [online] URL: https://population.un.org/wpp

Verburg, P. H., P. P. Schot, M. J. Dijst, and A. Veldkamp. 2004. Land use change modelling: current practice and research priorities. GeoJournal 61:309-324. https://doi.org/10.1007/ s10708-004-4946-y

van den Bosch, M., and A. Ode Sang. 2017. Urban natural environments as nature-based solutions for improved public health - a systematic review of reviews. Environmental Research 158:373-384. http://dx.doi.org/10.1016/j.envres.2017.05.040

Westerink, J., D. Haase, A. Bauer, J. Ravetz, F. Jarrige, and C. Aalbers. 2013. Dealing with sustainability trade-offs of the compact city in peri-urban planning across European city regions. European Planning Studies 25(4):473-497. http://dx.doi. org/10.1080/09654313.2012.722927

White, R. R. 2002. Building the ecological city. CRC, Boca Raton, Florida, USA.

Wolff, M., A. Haase, D. Haase, and N. Kabisch. 2017. The impact of urban regrowth on the built environment. Urban Studies 54 (12):2683-2700. https://doi.org/10.1177/0042098016658231

Wolff, M., and D. Haase. 2019. Mediating sustainability and liveability - turning points of green space supply in European cities. Frontiers in Environmental Science 7:61. https://doi. org/10.3389/fenvs.2019.00061

Wolff, M., D. Haase, and A. Haase. 2018. Compact or spread? A quantitative spatial model of urban areas in Europe since 1990. PLoS ONE 13(2):e0192326. https://doi.org/10.1371/journal. pone. 0192326

Wolff, M., A. Haase, D. Haase, and N. Kabisch. 2016. The impact of urban regrowth on the built environment. Urban Studies 54 (12):2683-2700. https://doi.org/10.1177/0042098016658231

Wolff, M., A. Mascarenhas, A. Haase, D. Haase, E. Andersson, S. T. Borgström, J. Kronenberg, E. Laszkiewicz, and M. Biernacka. 2022. Conceptualizing multidimensional barriers: a framework for assessing constraints in realizing recreational benefits of urban green spaces. Ecology and Society, in press.

Wolff, M., and T. Wiechmann. 2018. Urban growth and decline: Europe's shrinking cities in a comparative perspective 1990-2010. European Urban and Regional Studies 25(2):122-139. https://doi. org/10.1177/0969776417694680

Zabel, R., and Y. Kwon. 2021. Evolution of urban development and regeneration funding programs in German cities. Cities 111:103008. https://doi.org/10.1016/j.cities.2020.103008

Ziter, C. 2016. The biodiversity-ecosystem service relationship in urban areas: a quantitative review. Oikos 125(6):761-768. https:// doi.org/10.1111/oik.02883 
Appendix 1. All spidergraphs calculated for the selected neighbourhood development areas

Please click here to download file 'appendix1.xlsx'. 